This is an unedited manuscript published in the Journal of Career Development. The final version might have undergone minor additional editing in style and content.

Please cite as:

Marciniak, J., Johnston, C.S., Steiner, R., \& Hirschi, A. (2020). Career Preparedness among Adolescents: A Review of Key Components and Directions for Future Research. Journal of Career Development (TBD), 1-23. doi:10.1177/0894845320943951

\title{
Career Preparedness among Adolescents: A Review of Key Components and Directions for Future Research
}

\author{
Julian Marciniak, Claire S. Johnston, Rebekka Steiner and Andreas Hirschi \\ Department of Work and Organisational Psychology, University of Bern
}

\section{Author's Note}

This research was supported by a research grant awarded to Andreas Hirschi by the Swiss State Secretariat for Education, Research and Innovation (SERI). The funding source had no involvement in study design, in the collection, analysis and interpretation of data, in the writing of the report, or in the decision to submit the article for publication.

Correspondence concerning this article should be addressed to Julian Marciniak, Department of Work and Organizational Psychology, University of Bern, Bern, Switzerland. E-mail: julian.marciniak@psy.unibe.ch, tel: +41 (0)31 63146 14, or to Andreas Hirschi, Department of Work and Organizational Psychology, University of Bern, Bern, Switzerland. E-mail: andreas.hirschi@psy.unibe.ch, tel: +41(0)316314045. 


\title{
Highlights
}

- Empirical literature on career preparedness is reviewed

- A multidimensional conceptualization of career preparedness is proposed

- A meta-framework summarizes the predictors and outcomes of career preparedness

- Gaps in the empirical work on career preparedness are identified

\begin{abstract}
Adolescents and students are faced with the developmental task of becoming prepared for a career and master future career transitions. Existing research has investigated a range of concepts relating to career preparedness, including predictors and outcomes. However, this body of work is fragmented as a number of different conceptualizations and measurements related to career preparedness exist. Thus, the goal of this review is to provide an overview of the different concepts that have been used to describe and measure career preparedness. Based on a comprehensive review of empirical articles on maturity, readiness, adaptability, preparedness, and preparation, we propose an organizing framework of the diverse attitudes, knowledge and competencies, and behaviors required for career preparedness. We also review the empirical research on predictors and outcomes of career preparedness. We close by identifying issues in the conceptualization and measurement of different constructs and provide suggestions for future research, and implications for theory and practice.
\end{abstract}

Keywords: career preparedness; adolescents; students; maturity; readiness; adaptability. 


\section{Career Preparedness Among Adolescents: A Review of Key Components and Directions for Future Research}

Preparing for a career is a key developmental task of adolescence (Savickas, 2002; Super, Savickas, \& Super, 1996) and is a subject that has also been investigated in university students. A focus on these early career groups is especially relevant considering that individuals are increasingly spending a longer time in education, thereby delaying the entry to the working world (Ni Bhrolchain \& Beaujouan, 2013). Adequate career preparedness is important because early career experiences influence future work experiences as laid out in the life-course perspective on career development (e.g., Super et al., 1996) and insufficient preparedness may cause vocational problems (Skorikov, 2007). Early work in this field largely aimed to identify the factors which contribute to an individual's vocational or career maturity (Super, 1955) and readiness (Phillips \& Blustein, 1994) to make a well-founded career decision. More recently, research expanded this focus with constructs such as career adaptability (Savickas, 1997), preparation (Skorikov, 2007), and preparedness (Lent, 2013) that incorporate a number of aspects necessary to become prepared for a career.

The diversity of approaches to conceptualize career preparedness are valuable, yet it means that the research is largely dominated by individual studies-with the exception of reviews and meta-analyses for career maturity (Patton \& Lokan, 2001; Prideaux \& Creed, 2001) and career adaptability (Johnston, 2018; Rudolph, Lavine, \& Zacher, 2017). However, upon closer inspection, it becomes apparent that this body of research is conceptually quite fragmented. Indeed, the jingle-jangle fallacy (Kelley, 1927) is quite apparent in this literature as researchers have used the same terms (e.g., career preparation) to refer to very different aspects of career preparedness (i.e., jingle fallacy). For example, in some studies preparedness includes academic preparation and noncognitive factors (Lombardi, Conley, Seburn, \& Downs, 2013), whereas for others (Peterson, Sampson, Lenz \& Reardon, 2002) career 
preparedness includes the cognitive and affective factors related to making effective career decisions. Furthermore, different labels (e.g., career readiness, maturity) have been used to refer to identical aspects of career preparedness (i.e., jangle fallacy) such that the same measure (i.e. the career development inventory; Lokan, 1984) has been used to measure both readiness and maturity. The presence of the jingle-jangle fallacy is problematic, as it suggests that there is a lack of consensus in the field as to how these constructs should be defined, operationalized, and measured. This state of the literature makes it difficult to generalize results across studies, creates ambiguity about what it means to be prepared, and how to best conceptualize and assess career preparedness in research. As such, this state of research also hampers further empirical progress and reduces the ability to derive research-based interventions in career development practice.

To address the problem of conceptual fragmentation, we review the different concepts that have been used to describe how adolescents and students prepare for a career. First, we review the concepts of maturity, readiness, adaptability, preparedness, and preparation. Second, we present an overview of their associated conceptualizations and measurement. Third, organize these diverse concepts and measures into a common framework of key components of career preparedness. Specifically, we propose that the term career preparedness is used as a higher-order umbrella term. Such an umbrella term does not replace more specific constructs (e.g., career adaptability), but instead allows for the organization and integration of various perspectives and measurement approaches. Based on a review of key measures and concepts, we define career preparedness as the attitudes, knowledge, competencies, and behaviors necessary to deal with expected and unexpected career transitions and changes. Fourth, we review the literature of predictors and outcomes of career preparedness. Fifth, we summarize the review findings into an integrative framework of career preparedness components, predictors, and outcomes. Finally, we conclude with a discussion of implications for future research and practice. 
Our review makes three main contributions to the literature: First, by reviewing and organizing the terms of maturity, readiness, adaptability, preparedness, and preparation into a framework, we help to provide clarity to this heterogeneous literature. Second, our review can lay the foundation for future research and inform the development of career development interventions. Third, our review helps to identify gaps in the existing literature and make suggestions for further empirical research as well as recommendations for additional theoretical developments and practice applications.

\section{Theoretical Approaches to Career Preparedness}

Despite the variety in constructs pertaining to career preparedness, they all share some basic theoretical assumptions and roots suggesting that they can be meaningfully organized into a more general framework of career preparedness. From a theoretical perspective, the herein reviewed constructs represent a historical progression of key ideas related to vocational development and can be traced back to the life-span, life-space theory of career development (Super, 1990). This theory proposed that individuals needed to display sufficient maturity or readiness, and their associated attitudes and competencies, to manage career developmental tasks (Super, 1990). More recent thinking on preparedness builds on this earlier work by proposing adaptability as a replacement of career maturity (Savickas, 1997; Super \& Knasel, 1981) and preparedness as a supplement to earlier conceptualizations focusing on career problem-solving (Lent, 2013). Also, some of the same aspects that were included in earlier notions of maturity and readiness are utilized in more recent conceptualizations of preparedness (e.g., confidence and planning, Skorikov, 2007).

\section{Vocational or Career Maturity}

The concept of maturity was first defined by Super as "the place reached on the continuum of vocational development from exploration to decline" (Super, 1955, p. 153). Thus, individuals need to display sufficient maturity to cope with the developmental tasks associated with a particular stage (Super et al., 1996). For example, in the exploration phase, 
which includes adolescence and extends to age 24 , the main task is to make a career choice which requires self and occupational exploration (Savickas, 2002). Thus, maturity in adolescence is evidenced by readiness for decision making and dealing with age-graded developmental tasks (Super et al., 1996).

Super's model of maturity included two dimensions: attitudes toward and competencies for developing a career (Super, 1955; Super et al., 1996). In the career context, attitudes capture an individual's thoughts and feelings towards making a career choice and entering the world of work (Crites, 1978). Based on the work of Super, Crites defined maturity as one's readiness for career decision-making (Crites, 1978; Crites \& Savickas, 1996) and also included vocational choice competencies attitudes. Subsequent refinements of the maturity model specifically include attitudes towards planning and exploration and the competencies of decision making and occupational information or knowledge (Savickas, 2002). For this manuscript, we subsequently consider attitudes as the summary evaluations, situated on a continuum from negative to positive, of oneself, others, or a particular topic or subject (Petty, Priester, \& Wegener, 1994).

\section{Career Readiness}

The term "readiness" has been defined in a number of ways. First, it can be seen as a synonym for maturity as it is part of the definition of maturity which is the readiness for making age-appropriate decisions (Super et al., 1996). Second, it has been used in specific reference to career choice readiness, in which the developmental processes of planning, exploring, and deciding are known collectively as readiness (Phillips \& Blustein, 1994). Third, the cognitive information processing (CIP) theory considers readiness for career problem-solving and decision-making as the capability of an individual to make appropriate career choices, while considering contextual influencing factors (Peterson et al., 2002). CIP theory suggests that there are three key knowledge or competence factors in making a career choice; self-knowledge, occupational knowledge, and decision-making competence (Peterson 
et al., 2002). In addition, the metacognitions of self-talk, self-awareness, and monitoring and controlling are required for the successful regulation of self- and occupational knowledge, and decision-making skills (Peterson et al., 2002).

\section{Career Adaptability}

Career adaptability was historically proposed as a replacement of the career maturity term (Savickas, 1997; Super \& Knasel, 1981). Featuring prominently in career construction theory, adaptability is defined as "a psychosocial construct that denotes an individual's readiness and resources for coping with current and imminent vocational development tasks, occupational transitions, and personal traumas" (Savickas, 2005, p. 51). The theoretical foundations of career adaptability proposed an adaptation sequence that includes a distinction between adaptivity (or adaptive readiness), adaptability resources, adapting responses, and adaptation results. Adaptivity includes trait-like psychological characteristics pertaining to one's readiness and willingness to adapt (Rudolph et al., 2017). Adaptability resources are the self-regulation strengths or capacities that individuals use to cope with career related changes and include concern, control, curiosity, and confidence (Savickas, 1997; Savickas \& Porfeli, 2012). Adapting responses are the behaviors individuals use in career development tasks such as planning or exploration (Rudolph et al., 2017). Adaptation results include indicators of fit, satisfaction, and well-being (Rudolph et al., 2017) and capture how well an individual has adapted. A review and meta-analysis on career adaptability (Johnston, 2018; Rudolph et al., 2017) showed significant relations among elements of this adaptation sequence but also that the distinction between these elements is not always straightforward.

\section{Career Preparedness and Career Preparation}

Career preparation can be seen as a developmental process that starts in childhood and continues into adulthood with adolescence characterized by exploration and career decisionmaking (Hartung, Porfeli \& Vondracek, 2005; Super, 1957). Skorikov (2007) observed that there is a lack of clarity concerning the exact content of career preparation, but building on 
career construction theory, proposed that career preparation be conceptualized as a combination of career decidedness, planning, and confidence. More recently Lent (2013) suggested that preparedness could be a supplement to planning and defined career preparedness as "a healthy state of vigilance regarding threats to one's career well-being as well as alertness to resources and opportunities on which one can capitalize" (p. 302). He proposed that individuals are increasingly facing unexpected events and obstacles which individuals need to be prepared for, but cannot plan for (Lent, 2013).

\section{Measurement of Career Preparedness}

As we have argued above, the career preparedness literature sometimes uses the same terms to refer to very different aspects of preparedness, or at times uses different labels to refer to conceptually identical aspects of preparedness. We hence took a bottom up approach to examine the terms maturity, readiness, adaptability, preparedness, and preparation have been conceptualized and measured in empirical studies. That is, we identified the measures used for each term as well as if particular dimensions or total scores were used.

\section{Literature Search and Coding of Articles}

To identify the different measurements of career preparedness used in the literature, we conducted a literature search covering peer-reviewed published articles. The literature search was conducted with SCOPUS, Web of Science, and PsycINFO to include articles published until the end of June 2019 and specified that the search terms career maturity, vocational maturity, career readiness, career adaptability, career adaptabilities, career adapt-abilities, career preparedness, or career preparation appeared in the abstract, title, or keywords. We did not limit our search to specific journals or research fields, but the articles needed to fulfill three criteria to be included for consideration: (1) published in English and after 2001; (2) quantitative empirical papers published in a peer-reviewed journal; and (3) included an adolescent or student (school and college / university) sample. We chose to limit our search to articles published after 2001 because two reviews on career maturity were 
published in 2001 (Patton \& Lokan, 2001; Prideaux \& Creed, 2001). With this limitation, no vocational maturity articles were identified as the term career maturity replaced vocational maturity. For career adaptability, because a review (Johnston, 2018) and meta-analysis (Rudolph et al., 2017) were recently published that included studies up until May 2016, we only searched for articles published after this date. From the 149 articles included in the review and meta-analysis, we only included 76 studies in our review that used an adolescent or student sample. Applying our criteria for the other search terms, the search generated a result of 484 articles. We removed 256 papers that pertained to educational policy or curriculum design, as their main focus was not on conducting research focused on one of the search terms. Including the 76 articles on career adaptability from the review and metaanalysis, this left a final sample of 304 articles that were included in this review (see Appendix A for a full list of included articles).

In order to facilitate the analysis, we coded each article: (1) to identify the different conceptualizations of career preparedness, we identified which of the above listed search term(s) were included in an article and how the authors conceptualized and defined this term; (2) we identified which measures authors used along with the particular sub dimensions that were included; and as a basis for the later parts of this review we also (3) identified all the predictors and outcomes that were included as well as details pertaining to the measurement of these variables.

To code the articles, three of the authors and a research assistant each coded a subsample of articles. Once the first round of coding was completed, each coder worked on a second subsample of articles that they did not code themselves, to ensure the integrity of the coding. Whenever codings were unclear or inconsistent, two coders discussed the best approach for coding the articles until the discrepancies were resolved. Table 1 provides an overview of the most common career preparedness measures, operationalizations, and example papers (consult Appendix B for a more exhaustive list). 


\section{Key Components of Career Preparedness}

After investigating the various measurements of career preparedness, we propose that different aspects of career preparedness can be meaningfully represented as focusing on (a)

attitudes, (b) knowledge and competencies, and/or (c) behaviors, as indicated in Figure 1 and Table 1. This reflects the idea by Savickas (2005) that successful career development depends on the $\mathrm{ABC}$ 's of career construction in terms of diverse attitudes, behaviors, and competencies that are needed to master vocational tasks, transitions, and challenges. Hence, we see career preparedness as an umbrella term that encompasses a range of more specific constructs (e.g., career maturity, career readiness, career adaptability), defined as the attitudes, knowledge, competencies and behaviors necessary to deal with expected and unexpected work-or career-related transitions and changes. This definition encompasses Lent's (2013) definition of career preparedness, but also extends the concept by integrating various concepts related to the field of career preparedness.

First, many of the measures reviewed above were used as measures of attitudes in the sense that they measure an individual's thoughts and feelings towards making a career choice and entering the world of work (Crites, 1978). In the case of the career preparedness research, numerous measures (e.g., CMI, CMI-R, CDI, and the CDI-A) all include an attitudes dimension. In contrast to overall measures of attitudes, some specific measures of targeted attitudes exist (e.g., career planning scale, Skorikov, 2007), or authors chose to use a subscale of a measure (e.g., CDI, CDI-A, and the CFI) that targets a specific attitude. Similarly, authors used the CAAS to provide a score for the individual attitudes of concern, control, curiosity, and confidence (also known as adaptability resources). As there are several measures for specific individual attitudes (e.g., planning, exploration, (un)certainty, (in)decisiveness, adaptability resources, outcome expectations, decision-making self-efficacy, career locus of control, and dysfunctional beliefs), we chose to list these attitudes separately in Figure 1. 
Second, a number of widely used measures (e.g., CMI, CMI-R, CDI, and CDI-A) included subscales that measure knowledge and competencies, that is, skills and abilities central to career development, which can be influenced and developed by the individual (Akkermans et al., 2013). Once again, sometimes authors chose to use total scores of career development knowledge using the CDI or CDI-A (a combination of knowledge of decisionmaking and knowledge of world of work) or career maturity competence, using the CMI-R. Other times, specific subscales or specific measures of other knowledge and competencies, such as, knowledge of decision-making were used. Sometimes a lack of this knowledge or information was measured. Other measures focused specifically on decision-making competence, or the lack thereof. Lastly, a number of other knowledge and competencies were frequently measured by custom items or infrequently occurring measures.

Third, a number of measures targeted at capturing behaviors were included by authors such as self and environment exploration. Here authors were clearly interested in the behavior of exploration in that measures asked, for example, whether or not individuals had actually engaged in an exploration behavior, such as gathering information about interesting career paths (e.g., Hirschi et al., 2015). This is distinct from the attitude of exploration presented above which captures an individual's willingness to engage exploration. Similarly, one study included a behavioral measure of career planning (e.g.," I have discussed my career plans with a career counsellor", Jawarneh, 2016). These behaviors of exploring and planning are also known as adapting responses (Hirschi et al., 2015; Rudolph et al., 2017). Additionally, career preparedness behaviors and actions (e.g., actively seeking career-related support) and implementing career information (e.g., starting an educational program after career exploration) are also included in the category of career preparedness behaviors.

\section{Predictors and Outcomes of Career Preparedness}

Based on the systematic review and integration described above, we set out to investigate which variables were investigated in empirical research as predictors and 
outcomes of various career preparedness aspects. To do so, in a first step, two of the authors considered which predictors and outcomes of career preparedness were frequently investigated, and identified possible higher-order categories of predictors and outcomes. We considered variables as predictors and outcomes if they were labelled as such by the authors of each study. In a second step, predictors and outcomes of career preparedness were grouped into the higher-order categories. In the following section we describe the results by illustrating the general mechanisms of the predictors and outcomes of career preparedness.

\section{Predictors of Career Preparedness}

Contextual predictors of career preparedness. Based on the reviewed studies, three categories of contextual predictors of career preparedness emerged: (1) family characteristics, (2) receiving social support from others, and (3) participation in a career intervention.

Family background. The family background plays an important role, as higher household income and parental education allow adolescents to seize more opportunities to develop career preparedness (Lee, Rojewski, \& Hill, 2013; Bae, 2017). Such a household may invest more resources into the development of an adolescents' career, by providing more funds for education (Yon et al., 2012) and by providing a psychologically stable household (Murphy, Marelich, Herbeck, \& Cook, 2016; Kim \& Oh, 2013). As a result, adolescents may experience more freedom to explore and prepare for their career.

Social support. The development of career preparedness occurs within the bounds of a social environment, where teachers, friends, and family provide emotional support and career guidance. Parents can take an active interest in their children's future career by for example talking with them about their vocational interests and abilities (e.g., Perry, Liu, \& Pabian, 2010; Amarnani, Garcia, Restubog, Bordia, \& Bordia, 2016; Bae, 2017; Guan et al., 2016). Additionally, parents may offer networking opportunities for their children and provide emotional support during difficult times (e.g., dealing with rejection in job search). Similar support may be offered from sources such as teachers or counsellors (e.g., Perry et al., 2010), 
institutional support (e.g., Clair et al., 2017), peers (e.g., Yon et al., 2012), and during classes (Lazarides, Rohowski, Ohlemann, \& Ittel, 2016). As a whole, social support assists the development of career preparedness attitudes (e.g., Öztemel \& Y1ldı-Akyol, 2019; Ataç, Dirik, \& Tetik, 2017) and helps adolescents to be more engaged in the process of making a career decision (Hirschi, Niles, \& Akos, 2011).

Career interventions. Career interventions can help to systematically increase one or more facets of career preparedness. Adolescents may be assisted in engaging in career exploration behaviors, learn more about the world of work, or learn about career decision strategies to increase self-efficacy. Interventions may be carried out in the form of a career choice intervention (e.g., Koivisto, Vinokur, \& Vuori, 2011), a career training (e.g., Koen, Klehe, \& Van Vianen, 2012), a career education module, course or program (e.g., Eryilmaz \& Kara, 2018; Park, 2015b), or a peer counselling program (Wong, Chui, Chan, Ting, \& Lam, 2016). Interventions enhancing adolescents' general psychological functioning or health, such as a cognitive-behavioral group therapy (Lim et al., 2010) or health interventions (Werch et al., 2008) also affect career preparedness in a positive way.

Individual predictors of career preparedness. Five categories of individual predictors of career preparedness emerged: (1) demographic characteristics, (2) educational attainment and school achievement, (3) personality and individual differences, (4) career related attitudes and motivations, and (5) work experience.

Demographic characteristics. Patton and Creed (2002) have noted that female adolescents may engage earlier than men in career exploration and career choices, but this difference diminishes with age. Some studies in our review support this assertion (e.g., Patton \& Creed, 2002; Bae, 2017), whereas others have not (e.g., Lee, 2001; Tian \& Fan, 2014). However, with progressing age, adolescents become more interested in their future careers and as such experience an increase in career preparedness (e.g., Creed \& Patton, 2003; Patton \& Creed, 2002). Country of origin (e.g., Clair et al., 2017; Xiao, Newmann, \& Chu, 2018), 
race (Clair et al., 2017), personal income, and unemployment status (Strauser et al., 2015) may provide more or fewer opportunities and resources to develop career preparedness.

Educational attainment and school achievement. High performing and achieving students may have a stronger focus on preparing themselves for further education and thereby develop career preparedness sooner than their counterparts (e.g., Hardré \& Hackett, 2015; Tian \& Fan, 2014; Creed, Patton, \& Prideaux, 2007). For example, Creed et al. (2007) found that higher levels of self-reported school achievement at grade eight was related to more career planning and exploration two years later.

Personality and individual differences. Personality can be broadly defined as stable individual differences in behavior, thought, and emotion (e.g., John \& Srivastava, 1999), and plays an important role in the development of career preparedness. For instance, Savickas (2013) describes the psychological trait of adaptivity, which helps to deal with uncertain tasks during the development of career preparedness. Hence, a variety of personality characteristics such as the big five traits (e.g., Stringer, Kerpelman, \& Skorikov, 2012; Li et al., 2015; Sverko \& Babarvic, 2019), core self-evaluations (Hirschi et al., 2015), proactive personality (Hirschi et al., 2015; Park, 2015a), hope or optimism (e.g., Buyukgoze-Kavas, 2016; Wilkins et al., 2014), emotional intelligence (Celik \& Storme, 2018), adjustment or cognitive flexibility, reflecting a person's flexibility and willingness to change (Chong \& Leong, 2017; Stringer et al., 2012), self-esteem (e.g., Ataç et al., 2017; Janeiro, 2010), and various aspects of self-efficacy like general self-efficacy (Yon et al., 2012) coping efficacy (Murphy et al., 2016), learning efficacy (Tsai, Hsu, \& Yang, 2017), and decision-making style or thinking style (e.g., Hardin \& Leong, 2004), and future time perspective (Janeiro, 2010) have been found to predict career preparedness in adolescents. Conversely, problematic personality traits like externality of control (Hirschi et al., 2011) or negative affectivity and social inhibition (Yates, Wong, Strauser, \& Sears, 2017) may inhibit the development of career preparedness. 
In addition, cognitive representations of personality, like self-concept or identity (e.g., Hughes, 2011) can predict differences in adolescents' career preparedness. Lastly, some studies found that stable individual differences in mental representations of the self in relation to significant others, that is, attachment style predicted career preparedness (e.g., Lee \& Hughey, 2001).

Career-related attitudes and motivation. Adolescents who possess favorable careerrelated attitudes and motivations may have clearer ideas about which career path they want to pursue, and as a result develop more career preparedness. These attitudes and motivations include career goals (e.g., Clair et al., 2017), career interests in terms of interest elevation and differentiation (Jaensch, Hirschi, \& Spurk, 2016), work values (Yon et al., 2012), perceived fit between interests and the characteristics of an individual's (expected) work environment (Patton \& Creed, 2007), work commitment (Creed \& Patton, 2003), or calling (Douglass, \& Duffy, 2014; Hirschi \& Herrmann, 2013), which have been found to predict career preparedness.

Work experiences. Having real experiences in the world of work is a way to foster career preparedness, as these experiences provide meaningful learning experiences which may inform future career paths (e.g., Flouri \& Buchanan, 2002; Creed et al., 2007; Xiao, Newman, \& Chu, 2018). For example, increasing work experience from grade eight to ten was accompanied by an increase in career planning and exploration among Australian high school students (Creed et al., 2007).

\section{Outcomes of Career Preparedness}

Career-and education-related outcomes. Achieving career preparedness ideally leads to favorable career outcomes as described by the career adaptability sequence (Rudolph et al., 2017), such as having more employment success (Pan et al., 2018), and satisfaction with their present career choice and persistence in their career choice (Amarnani et al., 2018; Kleiman et al., 2004). For those who did not make a school-to-work transition yet, career preparedness is 
related to more engagement in career information-seeking (Shevlin \& Millar, 2006), positive career-related outcomes such as clearer occupational plans (Busacca \& Taber, 2002), higher occupational status expectations (Patton \& Creed, 2007), stronger entrepreneurial intentions (Tolentino, Sedoglavich, Lu, Garcia, \& Restubog, 2014) increased vocational commitment, as well as identification with the vocational commitment over time (Negru-Subtirica, Pop, \& Crocetti, 2015), and more job offers (Kwok, Adams, \& Feng, 2012). Similarly, studies showed that career preparedness is related to positive academic outcomes, such as increased academic performance (Oliveira et al., 2017; Perry et al., 2010), academic satisfaction (2015; Tak \& Lee, 2003), and retention in STEM majors (Belser, Prescod, Daire, Dagley, \& Young, 2017).

Well-being outcomes. As alluded to in the introduction, preparing for a career is a key developmental task (e.g., Super, Savickas, \& Super, 1996) and as such is positively related to indicators of adolescents' well-being, such as emotional stability (Stringer et al., 2012), positive affect (Konstam, Celen-Demirtas, Tomek, \& Sweeney, 2015), life satisfaction (e.g., Kim, Ahn, \& Fouad, 2016; Konstam et al., 2015; Tak \& Lee, 2003), or effective functioning (Savickas, Briddick, \& Watkins, 2002). For example, Skorikov (2007) reports that career planning, career confidence, and an absence of career indecision to be predictors of wellbeing such as social adaptation, emotional stability, life-satisfaction, and self-actualization. Additionally, career preparedness was inversely related to depression and anxiety.

Other outcomes. Career preparedness was also found to influence other outcomes such as adolescents' self-esteem (Skorikov, 2007), interpersonal and future orientations (Savickas et al., 2002) or internal success beliefs (Janeiro \& Marques, 2010). For example, Janeiro and Marques (2010) found that career planning and career exploration were positively correlated with a future orientation, internal success, and self-esteem. 
An Integrative Framework of Career Preparedness Components, Predictors, and

\section{Outcomes}

Summarizing the previous sections, we provide an integrative framework which aims to summarize the reviewed predictors and outcomes of career preparedness (Figure 2). Leaning on the social-cognitive model of career self-management (Lent et al., 2016), we propose a reciprocal relation between the three career preparedness components of attitudes, knowledge and competencies, and behaviors, where knowledge and competencies (e.g., knowledge of decision-making), and attitudes (e.g., curiosity) lead to action behaviors (e.g., exploration behavior). Based on Super and Hall (1978) we also presume that these behaviors in turn affect changes in knowledge and competencies (e.g., world of work knowledge), and attitudes (e.g., career decision-making self-efficacy). Career prepardeness behaviors lead to different outcomes (e.g., job offers/rejections), which act as a feedback mechanism, leading to changes in career preparedness.

Drawing on the social-cognitive model of career self-management (Lent et al., 2016), we moreover conceptualize the reviewed more distal individual (e.g., personality) and contextual factors (e.g., family background) as predictors of career preparedness. These more distal predictors may further influence more proximal personal and contextual influences on career preparedness in the current career context (e.g., career barriers; Park, 2015; disability status; Reid Yates, Wong, Strauser, \& Sears, 2017; social support; Rogers, Creed, \& Glendon, 2008), and may also support or interfere with career actions (i.e., moderate the effects of actions on outcomes).

\section{Discussion}

Given the presence of the jingle-jangle fallacy and conceptual fragmentation in the career preparedness literature, the main aim of this review was to provide an overview of the different concepts that have been used to describe how adolescents and students become prepared for a career. To achieve this, we reviewed the different conceptualizations and 
measurements of career preparedness, and presented an organizing framework of career preparedness, including its predictors and outcomes. This integration helps to provide conceptual clarity to the field which is important to facilitate communication, improve empirical analysis, and increase innovation in the field (Suddaby, 2010). We close this review with a list of issues and recommendations for future career preparedness research (see Table 2), and a discussion of theoretical and practical implications.

\section{Theoretical Implications}

Apart from the identified methodological aspects described in Table 2, addressing some substantive issues will contribute to advance the theoretical development of career preparedness. For example, Lent (2013) proposed that individuals also need to display preparedness for barrier management and identifying social support. Thus, in the exploration phase, adolescents should also be concerned with identifying potential barriers, considering the likelihood of encountering these barriers, and preparing coping strategies, while also looking to actively develop resources and identify sources of social support (Lent, Brown, \& Hackett, 2002). To test these assumptions, more empirical research is needed that focuses on barrier management and identifying social support as proactive career resource building behaviors that form an essential part of successful career development (Hirschi et al., 2018)

Secondly, it will be important to think about the complex, dynamic, and reciprocal relations between attitudes, knowledge and competencies, and behaviors. Indeed, some studies have examined the relations between aspects of career preparedness (e.g., Creed \& Patton, 2003; Gaffner \& Hazler, 2002; Hirschi et al., 2015; Punch, Creed, \& Hyde, 2005). For example, Creed and Patton (2003) showed that career preparedness attitudes (decidedness and self-efficacy) predicted career maturity attitudes (planning and exploration combined) and that career decidedness predicted career maturity knowledge (knowledge of decision-making and knowledge of world of work combined). Thus, we need more dynamic theories on career 
preparedness that can account for relations between different aspects of preparedness and possible feedback loops.

Importantly, while this review focused on adolescents and students, we suggest that career preparedness is relevant throughout one's career and as such, our multidimensional conceptualization and definition of career preparedness, as well as our suggestions for future research can also be applied with older populations. Because individuals need to be prepared for different career challenges throughout the life-course (i.e., making a career choice for adolescents and preparing for retirement for older workers) the content of career preparedness in terms of attitudes, knowledge, competencies, and behaviors remains highly relevant.

\section{Implications for Practice}

We suggest that the organizing framework proposed in this article will be a useful tool for career counseling practitioners, because the notion of preparedness is not limited to specific pre-defined tasks, such as making a career decision. Rather, as our review and framework illustrate, the notion of career preparedness is applicable to both predictable and unpredictable career transitions and changes. Our review can be used to guide the development and implementation of career guidance and counselling interventions that are focused on specific aspects of career preparedness. Here, practitioners could apply a select battery of questionnaires to assess relevant facets of career preparedness in order to identify strengths and weaknesses. This would allow practitioners to tailor an effective intervention based on the client's specific needs, for example, pertaining to improving career attitudes (e.g., curiosity) or career competencies (e.g., knowledge of decision-making). Attitudinal aspects may be improved by identifying strengths or reflecting on the importance of work, whereas knowledge and competencies may be strengthened by providing career education modules, which provide information about job search strategies or career opportunities. 
Relevant behaviors may be practiced in safe environments (e.g., roleplay), where specific phases of an upcoming career transition or change (e.g., job interview, first day on a new job) can be experienced without the fear of negative consequences.

The identified categories of predictors of career preparedness in the framework can also be a targeted to boost career preparedness in preventative interventions, while also providing a comprehensive reference point for developing preparedness in response to unexpected events. For example, the intervention by Koivisto, Vinokur, and Vuori (2011) included modules on lifelong learning and stress inoculation training to prepare the participants for career future which may include many changes, which can be riddled by barriers and setbacks. To assess the effectiveness of interventions it is recommended to not only examine changes in career preparedness, but to also examine the changes in the outcomes of career preparedness.

\section{Conclusion}

By reviewing conceptualizations and empirical research of career preparedness, we provided an organization of the diverse literature that can serve as a reference point for future research. The comprehensive framework of predictors and outcomes of career preparedness that we presented offers a succinct summary of existing research of preparedness and helps to clarify opportunities for future research. We also hope that this article lays a foundation for future theoretical and empirical work on career preparedness not only in adolescents and students, but also in adults. 


\section{References}

Akkermans, J., Brenninkmeijer, V., Huibers, M., \& Blonk, R. W. (2013). Competencies for the contemporary career: Development and preliminary validation of the Career Competencies Questionnaire. Journal of Career Development, 40(3), 245-267. doi:10.1177/0894845312467501

Amarnani, R. K., Garcia, P. R. J. M., Restubog, S. L. D., Bordia, P., \& Bordia, S. (2018). Do you think i'm worth it? The self-verifying role of parental engagement in career adaptability and career persistence among STEM students. Journal of Career Assessment, 26(1), 77-94. doi:10.1177/1069072716679925

Atac, L. O., Dirik, D., \& Tetik, H. T. (2018). Predicting career adaptability through selfesteem and social support: A research on young adults. International Journal for Educational and Vocational Guidance, 18(1), 45-61. doi:10.1007/s10775-017-9346-1

Bae, S.-M. (2017). An analysis of career maturity among Korean youths using latent growth modeling. School Psychology International, 38(4), 434-449.

doi:10.1177/0143034317709527

Belser, C. T., Prescod, D. J., Daire, A. P., Dagley, M. A., \& Young, C. Y. (2017). Predicting undergraduate student retention in STEM majors based on career development factors. The Career Development Quarterly, 65(1), 88-93. doi:10.1002/cdq.12082

Betz, N. E., Klein, K. L., \& Taylor, K. M. (1996). Evaluation of a short form of the career decision-making self-efficacy scale. Journal of Career Assessment, 4(1), 47-57. doi:10.1177/106907279600400103

Blau, G. (1993). Further exploring the relationship between job search and voluntary individual turnover. Personnel Psychology, 46(2), 313-330. doi:10.1111/j.17446570.1993.tb00876.x

Buyukgoze-Kavas, A. (2016). Predicting career adaptability from positive psychological traits. Career Development Quarterly, 64(2), 114-125. doi:10.1002/cdq.12045 
Busacca, L. A., \& Taber, B. J. (2002). The career maturity inventory-revised: A preliminary psychometric investigation. Journal of Career Assessment, 10(4), 441-455. doi:10.1177/1069072702238406

Cardoso, P., Janeiro, I. N., \& Duarte, M. E. (2018). Life design counseling group intervention with Portuguese adolescents: A process and outcome study. Journal of Career Development, 45(2), 183-196. doi:10.1177/0894845316687668

Celik, P., \& Storme, M. (2018). Trait emotional intelligence predicts academic satisfaction through career adaptability. Journal of Career Assessment, 26(4), 666-677. doi:10.1177/1069072717723290

Chartrand, J. M., Robbins, S. B., Morrill, W. H., \& Boggs, K. (1990). Development and validation of the Career Factors Inventory. Journal of Counseling Psychology, 37(4), 491-501. doi:10.1037/0022-0167.37.4.491

Chi, J., Leuty, M. E., Bullock-Yowell, E., \& Dahlen, E. R. (2018). Work value differentiation and profile elevation: What do they predict? Journal of Career Assessment. doi:10.1177/1069072718813368

Choi, K., \& Kim, D.-Y. (2013). A cross cultural study of antecedents on career preparation behavior: Learning motivation, academic achievement, and career decision selfefficacy. Journal of Hospitality, Leisure, Sport \& Tourism Education, 13, 19-32. doi:10.1016/j.jhlste.2013.04.00

Chong, S., \& Leong, F. T. L. (2017). Antecedents of career adaptability in strategic career management. Journal of Career Assessment, 25(2), 268-280. doi:10.1177/1069072715621522

Clair, R. S., Hutto, T., MacBeth, C., Newstetter, W., McCarty, N. A., \& Melkers, J. (2017). The "new normal": Adapting doctoral trainee career preparation for broad career paths in science. PloS one, 12(5), e0177035. doi:10.1371/journal.pone.0177035 
Creed, P. A., \& Patton, W. (2003). Predicting two components of career maturity in school based adolescents. Journal of Career Development, 29(4), 277-290. doi:10.1023/a:1022943613644

Creed, P. A., Patton, W., \& Prideaux, L.-A. (2007). Predicting change over time in career planning and career exploration for high school students. Journal of Adolescence, 30(3), 377-392. doi:10.1016/j.adolescence.2006.04.003

Creed, P., Prideaux, L.-A., \& Patton, W. (2005). Antecedents and consequences of career decisional states in adolescence. Journal of Vocational Behavior, 67(3), 397-412. doi:10.1016/j.jvb.2004.08.008

Crites, J. (1978). Administration and use manual for the Career Maturity Inventory. Monterey: CA: McGraw-Hill/CTB.

Crites, J. O., \& Savickas, M. L. (1996). Revision of the career maturity inventory. Journal of Career Assessment, 4(2), 131-138. doi:10.1177/106907279600400202

Douglass, R. P., \& Duffy, R. D. (2014). Calling and career adaptability among undergraduate students. Journal of Vocational Behavior, 86, 58-65. doi:10.1016/j.jvb.2014.11.003

Eryilmaz, A., \& Kara, A. (2018). Investigation of the effectiveness of a career adaptability program for prospective counsellors. Current Psychology, 1-9. doi:10.1007/s12144$018-9827-5$

Flouri, E., \& Buchanan, A. (2002). The role of work-related skills and career role models in adolescent career maturity. The Career Development Quarterly, 51(1), 36-43. doi:10.1002/j.2161-0045.2002.tb00590.x

Fouad, N. A., Ghosh, A., Chang, W. H., Figueiredo, C., \& Bachhuber, T. (2016). Career exploration among college students. Journal of College Student Development, 57(4), 460-464. 
Gaffner, D. C., \& Hazler, R. J. (2002). Factors related to indecisiveness and career indecision in undecided college students. Journal of College Student Development, 43(3), 317326.

Gati, I., Krausz, M., \& Osipow, S. H. (1996). A taxonomy of difficulties in career decision making. Journal of Counseling Psychology, 43(4), 510. doi:10.1037/00220167.43.4.510

Guan, M., Capezio, A., Restubog, S. L. D., Read, S., Lajom, J. A. L., \& Li, M. (2016). The role of traditionality in the relationships among parental support, career decisionmaking self-efficacy and career adaptability. Journal of Vocational Behavior, 94, 114-123. doi:10.1016/j.jvb.2016.02.018.

Hardin, E. E., \& Leong, F. T. (2004). Decision-making theories and career assessment: A psychometric evaluation of the decision making inventory. Journal of Career Assessment, 12(1), 51-64. doi:10.1177/1069072703257730

Hardré, P. L., \& Hackett, S. M. (2015). Understanding the graduate college experience: perceptual differences by degree type, point-in-program and disciplinary subgroups. Learning Environments Research, 18(3), 453-468. doi:10.1007/s10984-015-9194-1

Hartung, P. J., Porfeli, E. J., \& Vondracek, F. W. (2005). Child vocational development: A review and reconsideration. Journal of Vocational Behavior, 66(3), 385-419. doi:10.1016/j.jvb.2004.05.006

Hirschi, A., \& Herrmann, A. (2013). Calling and career preparation: Investigating developmental patterns and temporal precedence. Journal of Vocational Behavior, 83(1), 51-60. doi:10.1016/j.jvb.2013.02.008

Hirschi, A., Herrmann, A., \& Keller, A. C. (2015). Career adaptivity, adaptability, and adapting: A conceptual and empirical investigation. Journal of Vocational Behavior, 87, 1-10. doi:10.1016/j.jvb.2014.11.008 
Hirschi, A., Niles, S. G., \& Akos, P. (2011). Engagement in adolescent career preparation: Social support, personality and the development of choice decidedness and congruence. Journal of Adolescence, 34(1), 173-182.

doi:10.1016/j.adolescence.2009.12.009

Hirschi, A., Nagy, N., Baumeler, F., Johnston, C. S., \& Spurk, D. (2018). Assessing key predictors of career success: development and validation of the career resources questionnaire. Journal of Career Assessment, 26(2), 338-358. doi:

$10.1177 / 1069072717695584$

Hughes, C. (2011). The influence of self-concept, parenting style and individualismcollectivism on career maturity in Australia and Thailand. International Journal for Educational and Vocational Guidance, 11(3), 197-210. doi:10.1007/s10775-0119208-1

Jaensch, V. K., Hirschi, A., \& Spurk, D. (2016). Relationships of vocational interest congruence, differentiation, and elevation to career preparedness among university students. Zeitschrift für Arbeits- und Organisationspsychologie A\&O, 60(2), 79-89. doi:10.1026/0932-4089/a000210

Janeiro, I. N. (2010). Motivational dynamics in the development of career attitudes among adolescents. Journal of Vocational Behavior, 76(2), 170-177. doi:10.1016/j.jvb.2009.12.003

Janeiro, I. N., \& Marques, J. F. (2010). Career coping styles: Differences in career attitudes keamong secondary school students. International Journal for Educational and Vocational Guidance, 10(1), 35-48. doi:10.1007/s10775-009-9170-3

Jawarneh, M. (2016). Career maturity among university students in Jordan: The case for social studies. Australian Journal of Career Development, 25(3), 110-116. doi:10.1177/1038416216676807 
John, O. P., \& Srivastava, S. (1999). The Big Five trait taxonomy: History, measurement, and theoretical perspectives. In L. A. Pervin \& O. P. John (Eds.), Handbook of personality: Theory and research (Vol. 2, pp. 102-138). New York, NY: The Guilford Press.

Johnston, C. S. (2018). A systematic review of the career adaptability literature and future outlook. Journal of Career Assessment, 26(1), 3-30. doi:10.1177/1069072716679921

Jordan, S., Gessnitzer, S., \& Kauffeld, S. (2017). Develop yourself, develop others? How coaches and clients benefit from train-the-coach courses. Coaching, 10(2), 125-139. doi:10.1080/17521882.2017.1330353

Kelley, T. L. (1927). Interpretation of educational measurements. New York, NY: World Book.

Kim, S., Ahn, T., \& Fouad, N. (2016). Family influence on Korean students' career decisions. Journal of Career Assessment, 24(3), 513-526. doi:10.1177/1069072715599403

Kim, K.-N., \& Oh, S.-H. (2013). Effects of social constraints on career maturity: The mediating effect of the time perspective. Asia Pacific Education Review, 14(2), 221229. doi:10.1007/s12564-013-9240-6

Kleiman, T., Gati, I., Peterson, G., Sampson, J., Reardon, R., \& Lenz, J. (2004).

Dysfunctional thinking and difficulties in career decision making. Journal of Career Assessment, 12(3), 312-331. doi:10.1177/1069072704266673

Koen, J., Klehe, U. C., \& Van Vianen, A. E. (2012). Training career adaptability to facilitate a successful school-to-work transition. Journal of Vocational Behavior, 81, 395-408. doi:10.1016/j.jvb.2012.10.003

Koivisto, P., Vinokur, A. D., \& Vuori, J. (2011). Effects of career choice intervention on components of career preparation. The Career Development Quarterly, 59(4), 345366. doi:10.1002/j.2161-0045.2011.tb00074.x 
Konstam, V., Celen-Demirtas, S., Tomek, S., \& Sweeney, K. (2015). Career adaptability and subjective wellbeing in unemployed emerging adults: A promising and cautionary tale. Journal of Career Development, 42(6), 463-477. doi:10.1177/0894845315575151

Kwok, L., Adams, C. R., \& Feng, D. (2012). A comparison of graduating seniors who receive job offers and those who do not according to hospitality recruiters' selection criteria. International Journal of Hospitality Management, 31(2), 500-510. doi:10.1016/j.ijhm.2011.07.008

Lazarides, R., Rohowski, S., Ohlemann, S., \& Ittel, A. (2016). The role of classroom characteristics for students' motivation and career exploration. Educational Psychology, 36(5), 992-1008. doi:10.1080/01443410.2015.1093608

Lee, H.-Y., \& Hughey, K. F. (2001). The relationship of psychological separation and parental attachment to the career maturity of college freshmen from intact families Journal of Career Development, 27(4), 279-293. doi:10.1177/089484530102700404

Lee, I. H., Rojewski, J. W., \& Hill, R. B. (2013). Classifying Korean adolescents’ career preparedness. International Journal for Educational and Vocational Guidance, 13(1), 25-45. doi:10.1007/s10775-012-9236-5

Lee, K.-H. (2001). A cross-cultural study of the career maturity of Korean and United States high school students. Journal of Career Development, 28(1), 43-57. doi: $10.1177 / 089484530102800104$

Lent, R. W., Ezeofor, I., Morrison, M. A., Penn, L. T., \& Ireland, G. W. (2016). Applying the social cognitive model of career self-management to career exploration and decisionmaking. Journal of Vocational Behavior, 93, 47-57. doi:10.1016/j.jvb.2015.12.007

Lent, R. W. (2013). Career-life preparedness: Revisiting career planning and adjustment in the new workplace. The Career Development Quarterly, 61(1), 2-14. doi:10.1002/j.2161-0045.2013.00031.x 
Lent, R. W., Brown, S. D., \& Hackett, G. (2002). Social cognitive career theory. In D. Brown (Ed.), Career choice and development (4th ed., pp. 255-311). San-Francisco, CA: Jossey-Bass.

Li, Y., Guan, Y., Wang, F., Zhou, X., Guo, K., Jiang, P., ... Fang, Z. (2015). Big five personality and BIS/BAS traits as predictors of career explorations: The mediation role of career adaptability. Journal of Vocational Behavior, 89, 39-45. doi:10.1016/j.jvb.2015.04.006

Lim, J. Y., Kim, M. A., Kim, S. Y., Kim, E. J., Lee, J. E., \& Ko, Y. K. (2010). The effects of a cognitive-behavioral therapy on career attitude maturity, decision making style, and self-esteem of nursing students in Korea. Nurse Education Today, 30(8), 731-736. doi:10.1016/j.nedt.2010.01.014

Lokan, J. (1984). Career Development Inventory Australia: Manual. Victoria, Australia: Consulting Psychologists Press.

Lombardi, A. R., Conley, D. T., Seburn, M. A., \& Downs, A. M. (2013). College and career readiness assessment: Validation of the key cognitive strategies framework. Assessment for effective intervention, 38(3), 163-171. doi: $10.1177 / 1534508412448668$

Murphy, D. A., Marelich, W. D., Herbeck, D. M., \& Cook, M. (2016). Career readiness and externalizing behaviors of children affected by maternal HIV/AIDS: 15 -year outcomes of the PACT study. Vulnerable Children and Youth Studies, 11(3), 223-237. doi:10.1080/17450128.2016.1217113

Ni Bhrolchain, M., \& Beaujouan, E. (2013). Longer time spent in education means starting families later in life (ESRC Centre for Population Change Briefing Papers 11). Retrieved from http://www.cpc.ac.uk/publications/briefing_papers.php Negru-Subtirica, O., Pop, E. I., \& Crocetti, E. (2015). Developmental trajectories and reciprocal associations between career adaptability and vocational identity: A three- 
wave longitudinal study with adolescents. Journal of Vocational Behavior, 88, 131142. doi:10.1016/j.jvb.2015.03.004

Oliveira, Í. M., Taveira, M., \& Porfeli, E. J. (2017). Career preparedness and school achievement of portuguese children: Longitudinal trend articulations. Frontiers in Psychology, 8, 618. doi:10.3389/fpsyg.2017.00618

Osipow, S. H. (1987). Manual for career decision scale. Odessa, FL: Psychological Assessment Resources, Incorporated.

Öztemel, K., \& Y1ldz-Akyol, E. (2019). The predictive role of happiness, social support, and future time orientation in career adaptability. Journal of Career Development. doi:10.1177/0894845319840437

Park, I.-J. (2015a). The role of affect spin in the relationships between proactive personality, career indecision, and career maturity. Frontiers in Psychology, 6, 1754. doi:10.3389/fpsyg.2015.01754

Park, S. (2015b). Effects of discipline-based career course on nursing students' career search self-efficacy, career preparation behavior, and perceptions of career barriers. Asian Nursing Research, 9(3), 259-264. doi:10.1016/j.anr.2015.06.003

Patton, W., \& Creed, P. (2007). The relationship between career variables and occupational aspirations and expectations for Australian high school adolescents. Journal of Career Development, 34(2), 127-148. doi:10.1177/0894845307307471

Patton, W., \& Creed, P. A. (2002). The relationship between career maturity and work commitment in a sample of Australian high school students. Journal of Career Development, 29(2), 69-85. doi:10.1023/A:1019981502852

Patton, W., \& Lokan, J. (2001). Perspectives on Donald Super's construct of career maturity. International Journal for Educational and Vocational Guidance, 1(1), 31-48. doi:10.1023/A:1016964629452 
Perry, J. C., Liu, X., \& Pabian, Y. (2010). School engagement as a mediator of academic performance among urban youth: The role of career preparation, parental career support, and teacher support. The Counseling Psychologist, 38(2), 269-295. doi:10.1177/0011000009349272

Peterson, G. W., Sampson Jr, J. P., Lenz, J. G., \& Reardon, R. C. (2002). A cognitive information processing approach to career problem solving and decision making. In D. Brown \& Associates (Eds.), Career Choice and Development (4th ed., pp. 312-369). San Francisco, CA: Jossey-Bass.

Petty, R. E., Priester, J. R., \& Wegener, D. T. (1994). Cognitive processes in attitude change. In R. S. Wyer \& T. K. Srull (Eds.), Handbook of social cognition (2nd ed., pp. 69142). Hillsdale, NJ: Erlbaum.

Phillips, S. D., \& Blustein, D. L. (1994). Readiness for career choices: Planning, exploring, and deciding. The Career Development Quarterly, 43(1), 63-73. doi:10.1002/j.21610045.1994.tb00847.x

Prideaux, L.-A., \& Creed, P. A. (2001). Career maturity, career decision-making self-efficacy and career indecision: A review of the accrued evidence. Australian Journal of Career Development, 10(3), 7-12. doi:10.1177/103841620101000303

Punch, R., Creed, P. A., \& Hyde, M. (2005). Predicting career development in hard-ofhearing adolescents in Australia. Journal of Deaf Studies and Deaf Education, 10(2), 146-160. doi:10.1093/deafed/eni015

Rogers, M. E., Creed, P. A., \& Glendon, I. A. (2008). The role of personality in adolescent career planning and exploration: A social cognitive perspective. Journal of Vocational Behavior, 73(1), 132-142. doi:10.1016/j.jvb.2008.02.002

Rottinghaus, P. J., Day, S. X., \& Borgen, F. H. (2005). The Career Futures Inventory: A measure of career-related adaptability and optimism. Journal of Career Assessment, 13(1), 3-24. doi:10.1177/1069072704270271 
Rottinghaus, P. J., Eshelman, A., Gore, J. S., Keller, K. J., Schneider, M., \& Harris, K. L. (2017). Measuring change in career counseling: Validation of the Career Futures Inventory-Revised. International Journal for Educational and Vocational Guidance, 17(1), 61-75. doi:10.1007/s10775-016-9329-7

Rudolph, C. W., Lavigne, K. N., \& Zacher, H. (2017). Career adaptability: A meta-analysis of relationships with measures of adaptivity, adapting responses, and adaptation results. Journal of Vocational Behavior, 98, 17-34. doi:10.1016/j.jvb.2016.09.002

Savickas, M. L. (1997). Career adaptability: An integrative construct for life-span, life-space theory. The Career Development Quarterly, 45(3), 247-259. doi:10.1002/j.21610045.1997.tb00469.x

Savickas, M. L. (2002). Career construction: A developmental theory of vocational behavior. In D. B. Associates (Ed.), Career Choice and Development (4 ed., pp. 149-205). San Francisco, CA: Jossey-Bass.

Savickas, M. L. (2005). The theory and practice of career construction. In S. Brown \& R. Lent (Eds.), Career development and counseling: Putting theory and research to work (Vol. 1, pp. 42-70). Hoboken, New Jersey: Wiley \& Sons.

Savickas, M. L. (2013). Career construction theory and practice. In S. D. Brown \& R. W. Lent (Eds.), Career development and counseling: Putting theory and research to work (2nd ed., pp. 42-70). Hoboken, NJ: Wiley.

Savickas, M. L., Briddick, W. C., \& Watkins, C. E. (2002). The relation of career maturity to personality type and social adjustment. Journal of Career Assessment, 10(1), 24-49. doi:10.1177/1069072702010001002

Savickas, M. L., \& Porfeli, E. J. (2012). Career Adapt-Abilities Scale: Construction, reliability, and measurement equivalence across 13 countries. Journal of Vocational Behavior, 80(3), 661-673. doi:10.1016/j.jvb.2012.01.011 
Savickas, M. L., Porfeli, E. J., Hilton, T. L., \& Savickas, S. (2018). The Student Career Construction Inventory. Journal of Vocational Behavior, 106, 138-152. doi: 10.1016/j.jvb.2018.01.009

Shevlin, M., \& Millar, R. (2006). Career education: An application of latent growth curve modelling to career information-seeking behaviour of school pupils. British Journal of Educational Psychology, 76(1), 141-153. doi:10.1348/000709904x22386

Skorikov, V. (2007). Continuity in adolescent career preparation and its effects on adjustment. Journal of Vocational Behavior, 70(1), 8-24. doi:10.1016/j.jvb.2006.04.007

Strauser, D., Klosky, J. L., Brinkman, T. M., Wong, A. W., Chan, F., Lanctot, J., . . Ness, K. K. (2015). Career readiness in adult survivors of childhood cancer: A report from the St. Jude Lifetime Cohort Study. Journal of Cancer Survivorship, 9(1), 20-29. doi:10.1007/s11764-014-0380-4

Stringer, K., Kerpelman, J., \& Skorikov, V. (2012). A longitudinal examination of career preparation and adjustment during the transition from high school. Developmental Psychology, 48(5), 1343-1354. doi:10.1037/a0027296

Stumpf, S.A, Colarelli, S. M., \& Hartman, K. (1983). Development of the Career exploration Survey (CES), JVB 22, 191-226. doi:10.1016/0001-8791(83)90028-3

Suddaby, R. (2010). Construct clarity in theories of management and organization. The Academy of Management Review, 35, 346-357. Doi:10.5465/AMR.2010.51141319

Super, D. E. (1955). Dimensions and measurement of vocational maturity. Teachers College Record, 57, 151-163.

Super, D. E. (1990). A life-span, life-space approach to career development. In D. Brown \& L. Brooks (Eds.), Career choice and development: Applying contemporary theories to practice (2 ed., pp. 197-261). San Francisco: Jossey-Bass.

Super, D. E., \& Hall, D. T. (1978). Career development: Exploration and planning. Annual Review of Psychology, 29(1), 333-372. doi:10.1146/annurev.ps.29.020178.002001 
Super, D. E., \& Knasel, E. G. (1981). Career development in adulthood: Some theoretical problems and a possible solution. British Journal of Guidance and Counselling, 9, 194-201.

Super, D. E., Savickas, M. L., \& Super, C. M. (1996). The life span, life space approach to careers. In D. Brown, L. Brooks, \& Associates (Eds.), Career choice and development: Applying contemporary theories to practice (3rd ed., pp. 121-178). San Francisco, CA: Jossey-Bass.

Sverko, I., \& Babarovic, T. (2019). Applying career construction model of adaptation to career transition in adolescence: A two-study paper. Journal of Vocational Behavior, 111, 59-73. doi:10.1016/j.jvb.2018.10.011

Tak, J., \& Lee, K.-H. (2003). Development of the Korean career indecision inventory. Journal of Career Assessment, 11(3), 328-345. doi:10.1177/1069072703254503

Talib, M. A., \& Aun, T. K. (2009). Predictors of career indecision among malaysian undergraduate students. European Journal of Social Sciences, 8(2), 215-224.

Thompson, A. S., Lindeman, R. H., Super, D., Jordaan, J., \& Myers, R. (1981). Career development inventory (Vol. 1). Palo Alto, CA: Consulting Psychologists Press

Tian, Y., \& Fan, X. (2014). Adversity quotients, environmental variables and career adaptability in student nurses. Journal of Vocational Behavior, 85, 251-257. doi:10.1016/j.jvb.2014.07.006

Tolentino, L. R., Sedoglavich, V., Lu, V. N., Garcia, P. R. J. M., \& Restubog, S. L. D. (2014). The role of career adaptability in predicting entrepreneurial intentions: A moderated mediation model. Journal of Vocational Behavior, 85, 403-412. doi:10.1016/j.jvb.2014.09.002

Tsai, C.-T. S., Hsu, H., \& Yang, C.-C. (2017). Career decision self-efficacy plays a crucial role in hospitality undergraduates' internship efficacy and career preparation. Journal 
of Hospitality, Leisure, Sport \& Tourism Education, 21(A), 61-68. doi:10.1016/j.jhlste.2017.08.002

Werch, C. E., Bian, H., Moore, M. J., Ames, S. C., DiClemente, C. C., Thombs, D., \& Pokorny, S. B. (2008). Brief multiple behavior health interventions for older adolescents. American Journal of Health Promotion, 23(2), 92-96. doi:10.4278/ajhp.07040533

Wilkins, K. G., Santilli, S., Ferrari, L., Nota, L., Tracey, T. J., \& Soresi, S. (2014). The relationship among positive emotional dispositions, career adaptability, and satisfaction in Italian high school students. Journal of Vocational Behavior, 85, 329338. doi:10.1016/j.jvb.2014.08.004

Wong, S.-W., Chui, Y. H., Chan, Y. C., Ting, S. R., \& Lam, J. K. (2016). Enhancing students career readiness through peer counselling programme in Hong Kong. Australian Journal of Career Development, 25(1), 23-32. doi:10.1177/1038416215612821

Xiao, J. J., Newman, B. M., \& Chu, B. S. (2018). Career Preparation of High School Students: A Multi-Country Study. Youth \& Society, 50(6), 818-840. doi:10.1177/0044118x16638690

Yates, J. A. R., Wong, A. W. K., Strauser, D. R., \& Sears, S. J. H. (2017). The impact of type D personality traits on the career readiness of college students with and without disabilities. Rehabilitation Counseling Bulletin, 60(2), 67-76. doi:10.1177/0034355215610082

Yon, K. J., Joeng, J.-R., \& Goh, M. (2012). A longitudinal study of career maturity of Korean adolescents: The effects of personal and contextual factors. Asia Pacific Education Review, 13(4), 727-739. doi:10.1007/s12564-012-9232-y 
Table 1

Overview of Most Frequent Career Preparedness Measures and Classification into Attitudes, Knowledge and Competencies, and Behavior

\begin{tabular}{|c|c|c|c|c|}
\hline Scale & Authors & Operationalization & $\begin{array}{l}\text { Dimensions of } \\
\text { career } \\
\text { preparedness }\end{array}$ & Example papers \\
\hline $\begin{array}{l}\text { Career Maturity } \\
\text { Inventory (CMI); } \\
\text { Career Maturity } \\
\text { Inventory Revised } \\
\text { (CMI-R) }\end{array}$ & $\begin{array}{l}\text { Crites, 1978; } \\
\text { Crites \& } \\
\text { Savickas, } 1996\end{array}$ & $\begin{array}{l}\text { The CMI-R consists of an attitude scale ( } 25 \text { items) and } \\
\text { competence test ( } 25 \text { items). The original inventory (CMI) } \\
\text { consists of } 75 \text { items, and is seldomly used. The attitude scale } \\
\text { assesses attitudes towards decision-making, whereas the } \\
\text { competence test assesses comprehension and problem-solving } \\
\text { abilities in regards to career decision-making. }\end{array}$ & $\begin{array}{l}\text { Attitudes; } \\
\text { knowledge and } \\
\text { competencies }\end{array}$ & $\begin{array}{l}\text { Busacca \& Taber } \\
\text { (2002); } \\
\text { Creed et al., } \\
(2007)\end{array}$ \\
\hline $\begin{array}{l}\text { Career Development } \\
\text { Inventory (CDI); } \\
\text { Career Development } \\
\text { Inventory-Australia } \\
\text { (CDI-A) }\end{array}$ & $\begin{array}{l}\text { Thompson et } \\
\text { al., 1981; } \\
\text { Lokan, } 1984\end{array}$ & $\begin{array}{l}\text { The CDI measures two broad aspects, namely career } \\
\text { development attitude (CDA; } 28 \text { items) and career } \\
\text { development knowledge (CDK; } 44 \text { items). CDK assesses } \\
\text { decision-making skills and knowledge about the world of } \\
\text { work; CDA assesses attitudes towards career planning and } \\
\text { exploration. The Career Development Inventory-Australia has } \\
\text { been used the most in research. }\end{array}$ & $\begin{array}{l}\text { Attitudes; } \\
\text { knowledge and } \\
\text { competencies }\end{array}$ & $\begin{array}{l}\text { Creed et al., } \\
\text { (2002); Janeiro } \\
\text { (2010); Rogers, } \\
\text { Creed, \& } \\
\text { Glendon (2008) }\end{array}$ \\
\hline $\begin{array}{l}\text { Career Factors } \\
\text { Inventory (CFI) }\end{array}$ & $\begin{array}{l}\text { Chartrand, } \\
\text { Robbins, } \\
\text { Morrill, \& } \\
\text { Boggs, } 1990\end{array}$ & $\begin{array}{l}\text { The CFI ( } 21 \text { items) measures four dimensions of the career } \\
\text { decision-making process, which are grouped into information } \\
\text { needs and decision needs. Information needs are comprised of } \\
\text { need for career information ( } 6 \text { items) and need for self- } \\
\text { knowledge ( } 4 \text { items). Decision needs include career choice } \\
\text { anxiety ( } 6 \text { items) and generalized indecisiveness ( } 5 \text { items). }\end{array}$ & $\begin{array}{l}\text { Attitudes; } \\
\text { knowledge and } \\
\text { competencies }\end{array}$ & $\begin{array}{l}\text { Talib \& Aun, } \\
\text { 2009; Gaffner \& } \\
\text { Hazler, } 2002\end{array}$ \\
\hline $\begin{array}{l}\text { Career Thoughts } \\
\text { Inventory (CTI) }\end{array}$ & $\begin{array}{l}\text { Peterson et al., } \\
2002\end{array}$ & $\begin{array}{l}\text { The CTI ( } 48 \text { items) assesses dysfunctional thinking as it } \\
\text { interferes with the career decision-making process or as it } \\
\text { inhibits career problem solving. It is comprised of the }\end{array}$ & $\begin{array}{l}\text { Attitudes; } \\
\text { knowledge and } \\
\text { competencies }\end{array}$ & $\begin{array}{l}\text { Belser et al., } \\
\text { (2017); Yates et } \\
\text { al., (2017) }\end{array}$ \\
\hline
\end{tabular}


decision-making confusion (14 items), commitment anxiety

(10 items), external conflict (5 items) subscales.

Career Decision Making Difficulties

Questionnaire

Gati, Krausz, \& Osipow, 1996

Career AdaptAbilities Scale (CAAS)

Student Career Construction Inventory (SCCI)

Career Preparation Behaviors Scale

Career Futures Inventory

Rottinghaus et al., 2005

Savickas, Porfeli, Hilton, \& Savickas, 2018

Blau, 1993

The CDDQ (44 items) assesses the lack of readiness, lack of information and inconsistent information.

Savickas \& Porfeli, 2012

The CAAS (24 items) assesses the four career adaptability resources concern, control, curiosity, and confidence (6 items each), which help manage occupational transitions, developmental tasks, and work traumas.

The SCCI (18 items), assesses career adapting responses, which have been laid out in the theoretical model of career adaptation (Savickas, 2013). The SCCI is comprised of four scales, which assess crystallizing a vocational self-concept (6 items), exploring to gather information about occupations (3 items), deciding to commit to an occupational choice (5 items), and preparing to implement that choice (4 items).

The scale (6 items) is a sub-scale of a more general job search behavior scale (16 items) and assesses the amount of preparatory job search behavior that an individual has engaged in.

The CFI (25 items) measures three factors of career selfmanagement: career adaptability (11 items), career optimism (11 items) and perceived knowledge of the employment market (3 items).

CMI Form C
Savickas \&
Attitudes; knowledge and competencies

\section{Attitudes}

\section{Tetik (2018);}

Atac, Dirik, \&

Sverko \&

Babarovic (2019)

Behaviors

\section{Sverko \&}

Babarovic (2019);

Fouad et al.

(2016)

Behaviors

Tsai et al., (2017); Choi \& Kim (2013)

Attitudes;

Jordan, knowledge and competencies

\section{Gessnitzer, \&} Kauffeld (2017); Rottinghaus et al. (2017)

Attitudes
Cardoso, Janeiro, 
Porfeli, 2011 choice readiness. Three scale scores reflect adaptability resources (concern, curiosity, and confidence; 6 items each) and a score for consultation (6 items) that reflects an individual's relational style in making occupational choices.

Career Decision

Making Self-

Efficacy Scale -

Short Form

Career Exploration

Survey

Betz, Klein \& Taylor, 1996 ability to make career-oriented decisions.

Stumpf et al., 1983
The CDMSE (25 items) assesses the confidence regarding the

Career Decision Scale
Osipow, 1987 exploration (6 items), self-exploration (5 items), intendedsystematic exploration (3 items), frequency of seeking career information (1 item), amount of information (3 items), number of occupations considered (1 item), focus on how sure one feels in one's preference of an occupation, job, and organization (5 items), satisfaction with information (6 items), explorational stress (3 items), decisional stress (4 items), employment outlook (3 items), certainty of career exploration outcome (3 items), external search instrumentality (3 items), internal search instrumentality (4 items), method instrumentality (4 items), and importance of obtaining preferred position (5 items).

Consists of two subscales, the CDS-Indecision scale (CDS-I; 16 items) and the CDS-Certainty scale (CDS-C; 2 items). The CDS-I assesses career indecision and the CDS-C indicates the degree of certainty after having made a career decision.
\& Duarte (2018); Chi, Leuty, Bullock-Yowell, \& Dahlen (2018)

Perry, Liu, \& Pabian (2010); Creed, Prideaux, \& Patton (2005)

Behaviors

Hirschi, Niles, \& Akos (2011); Li et al., (2015).

Attitudes;

Skorikov (2007); knowledge and Stinger, competencies Kerpelman, \& Skorikov (2011); Creed, Prideaux, \& Patton (2005) 
Table 2

Summary of Recommendations for Improving Research on Career Preparedness

Issue $\quad$ Recommendations

Lack of clarity concerning which aspects of career preparedness are measured, in the sense that (1) researchers use total scores for multidimensional scales and (2) researchers use scales that are not unidimensional.

Lack of clarity concerning; (1) which aspect of career preparedness is of interest; (2) how these aspects were defined; and (3) the choice of a corresponding measure.

Lack of longitudinal research on the predictors and outcomes of career preparedness.

Lack of research that includes mediators and moderators.

Lack of research on objective real-world outcomes.
(1) Only use total score when a scale is unidimensional.

(2) Treat different aspects of career preparedness as separate dimensions and use an appropriate measure.

(1) Clearly state which aspect of preparedness is of interest.

(2) Give a clear definition of this aspect that is connected to theory.

(3) Choose the appropriate measure.

(1) Conduct more longitudinal research on career preparedness.

(2) Conduct research on the trajectory of career preparedness.

(1) Conduct research that includes mediators and moderators.

(2) Give attention to theory development that accounts for mediators and moderators.

(1) Conduct research that includes objective realworld outcomes such as educational and job success outcomes. 


\section{Components of Career Preparedness}

\begin{tabular}{|c|c|}
\hline $\begin{array}{l}\text { Attitudes } \\
\text { Career planning } \\
\text { Career exploration } \\
\text { Career (un)certainty } \\
\text { Career decidedness / indecision } \\
\text { Concern } \\
\text { Control } \\
\text { Curiosity } \\
\text { Confidence } \\
\text { Outcome expectations } \\
\text { Decision making self-efficacy } \\
\text { Career locus of control } \\
\text { Dysfunctional beliefs } \\
\text { Other attitudes (e.g. readiness to make a } \\
\text { career decision; readiness to engage in } \\
\text { vocational development behaviors) }\end{array}$ & $\begin{array}{l}\text { Knowledge and Competencies } \\
\text { Knowledge of decision-making } \\
\text { (Lack of) knowledge of preferred occupation } \\
\text { (Lack of) knowledge of world of work } \\
\text { Decision-making competence } \\
\text { Other knowledge and competencies (e.g. } \\
\text { career research skills; generating occupational } \\
\text { options) }\end{array}$ \\
\hline
\end{tabular}

\section{Behaviors}

Self-exploration

Environment exploration

Career planning

Decision making

Adapting responses (e.g., career exploration)

Career preparation actions and behaviors

(e.g., seek career support)

Implementation of career information (e.g.

start an educational program) 
Figure 1. Integrative framework of career preparedness as consisting of different attitudes, knowledge and competencies, and behaviors. Career planning and exploration appear in both the categories of attitudes and behaviors because they are conceptualized/operationalized as attitudes or behaviors in different studies.

\section{Individual}

- Demographic characteristics (e.g., age)

- Educational attainment and achievement (e.g., grades)

- Personality and individual differences

(e.g., big five personality traits)

- Career-related attitudes and motivations (e.g., work commitment)

- Work experiences (e.g., having a part-time job)

\begin{tabular}{ll|}
\multicolumn{1}{c|}{ Contextual } \\
- \\
Career interventions \\
(e.g., career counselling) \\
- \\
Family background \\
(e.g., household income) \\
Social support \\
(e.g. parental career support)
\end{tabular}

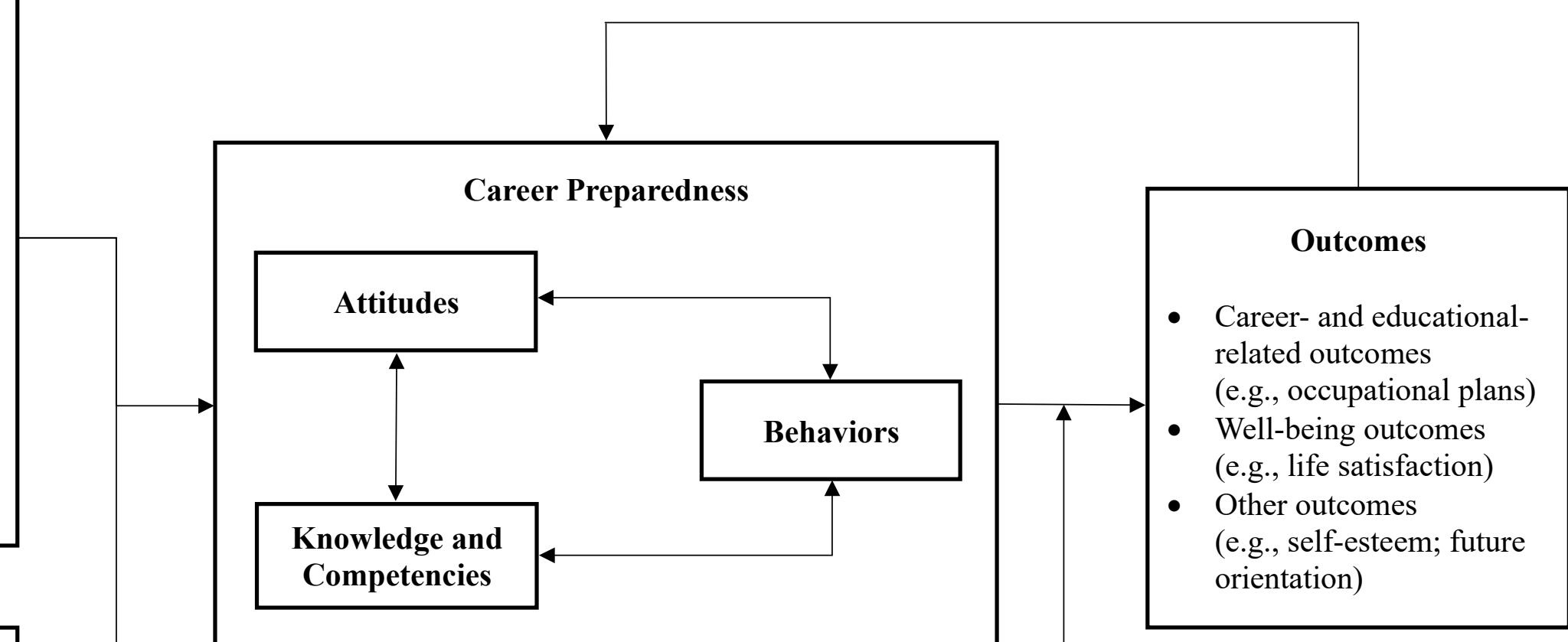


Figure 2. Integrative framework on predictors and outcomes of career preparedness. 


\section{Appendix A}

\section{Full Reference List of all Articles Included in the Review}

Abd-Hanid, H. (2007). The effectiveness of career exploration stage of career development in secondary schools in Dungun district of Terengganu., Universiti Putra Malaysia, Serdang.

Abele, A. E., \& Wiese, B. S. (2008). The nomological network of self-management strategies and career success. Journal of Occupational and Organizational Psychology, 81(4), 733-749. doi:10.1348/096317907X256726

Abidin, M. H. Z., Amata, S., Subhan, M., Mahmud, M. I., Ali, S., \& Bakar, A. Y. A. (2018). Career maturity among gifted and talented students in Malaysia. International Journal of Engineering and Technology(UAE), 7(2), 74-75. doi:10.14419/ijet.v7i2.10.10959

Akkermans, J., Paradnike, K., Van der Heijden, B., \& De Vos, A. (2018). The best of both worlds: The role of career adaptability and career competencies in students' well-being and performance. Frontiers in Psychology, 9, 13. doi:10.3389/fpsyg.2018.01678

Akos, P., Konold, T., \& Niles, S. G. (2004). A career readiness typology and typal membership in middle school. The Career Development Quarterly, 53(1), 53-66. doi:10.1002/j.2161-0045.2004.tb00655.x

Akpan, I. J. (2016). The efficacy of consulting practicum in enhancing students' readiness for professional career in management information systems: An empirical analysis.

Decision Sciences Journal of Innovative Education, 14(4), 412-440. doi:10.1111/dsji.12109

Albien, A. J., Kidd, M., Naidoo, A. V., \& Maree, J. G. (2019). Mixed-methods analysis of the applicability of the Career Adapt-Abilities Scale for isiXhosa-speaking South African township adolescents. International Journal for Educational and Vocational Guidance. doi:10.1007/s10775-019-09391-6

Allen, K. R., \& Bradley, L. (2015). Career counseling with juvenile offenders: Effects on selfefficacy and career maturity. Journal of Addictions \& Offender Counseling, 36(1), 2842. doi:10.1002/j.2161-1874.2015.00033.x

Amarnani, R. K., Garcia, P. R. J. M., Restubog, S. L. D., Bordia, P., \& Bordia, S. (2018). Do you think i'm worth it? The self-verifying role of parental engagement in career adaptability and career persistence among stem students. Journal of Career Assessment, 26(1), 77-94. doi:10.1177/1069072716679925

Ambiel, R. A. M., Carvalho, L. D., Martins, G. H., \& Tofoli, L. (2016). Comparing the adaptabilities of Brazilian adolescent students and adult workers. Journal of Vocational Behavior, 94, 20-27. doi:10.1016/j.jvb.2016.02.005

Ambiel, R. A. M., Martins, G. H., \& Hernández, D. N. (2018). Why do adolescents seek career counseling? a predictor study of Brazilian students. Trends in Psychology, 26(4), 1985-1998. doi:10.9788/TP2018.4-10En

Antonelli, K., Steverson, A., \& O'Mally, J. (2018). College graduates with visual impairments: A report on seeking and finding employment. Journal of Visual Impairment \& Blindness, 112(1), 33-45. doi:10.1177/0145482X1811200104

Ashari, Z. H. M., Azman, N., \& Rasul, M. S. (2019). Factors predicting career choice among Malaysian students in skills-based training institutions. International Journal for Educational and Vocational Guidance, 19(1), 19-39. doi:10.1007/s10775-018-9366-5

Atac, L. O., Dirik, D., \& Tetik, H. T. (2018). Predicting career adaptability through selfesteem and social support: A research on young adults. International Journal for Educational and Vocational Guidance, 18(1), 45-61. doi:10.1007/s10775-017-9346-1 
Athanasou, J. A. (1986). A behavioral checklist of career exploration activities for use in vocational guidance and research: A preliminary study. Behavior Change, 3(1), 48-52. doi:10.1017/S0813483900009104

Atitsogbe, K. A., Mama, N. P., Sovet, L., Pari, P., \& Rossier, J. (2019). Perceived employability and entrepreneurial intentions across university students and job seekers in togo: The effect of career adaptability and self-efficacy. Frontiers in Psychology, 10, 14. doi:10.3389/fpsyg.2019.00180

Atli, A. (2017). Five-factor personality traits as predictor of career maturity. Eurasian Journal of Educational Research, 68, 153-167. doi:10.14689/ejer.2017.68.8

Avram, E., Burtaverde, V., \& Zanfirescu, A.-S. (2019). The incremental validity of career adaptability in predicting academic performance. Social Psychology of Education: An International Journal, 1-16. doi:10.1007/s11218-019-09505-6

Autin, K. L., Douglass., R. P., Duffy, R. D., England, J. W., \& Allan, B. A. (2017). Subjective social status, work volition, and career adaptability: A longitudinal study. Journal of Vocational Behavior, 99, 1-10. doi:10.1016/j.jvb.2016.11.007

Babarović, T., \& Šverko, I. (2018). The validity of career decision-making difficulties questionnaire in croatia. Journal of Career Assessment. doi:10.1177/1069072717748960

Bae, S.-M. (2017). An analysis of career maturity among Korean youths using latent growth modeling. School Psychology International, 38(4), 434-449. doi:10.1177/0143034317709527

Balin, E., \& Hirschi, A. (2010). Who seeks career counselling? A prospective study of personality and career variables among Swiss adolescents. International Journal for Educational and Vocational Guidance, 10(3), 161-176. doi:10.1007/s10775-0109183-y

Bandura, A. (1990). Multidimensional Scales of Perceived Academic Efficacy. Stanford, CA: Stanford University.

Bato Çizel, R. (2018). Gender and emotional intelligence as predictors of tourism faculty students' career adaptability. Advances in Hospitality and Tourism Research, 6(2), 188-204. doi:10.30519/ahtr.431014

Belser, C. T., Prescod, D. J., Daire, A. P., Dagley, M. A., \& Young, C. Y. (2018). The influence of career planning on career thoughts in STEM-interested undergraduates. The Career Development Quarterly, 66(2), 176-181. doi:10.1002/cdq.12131

Belser, C. T., Prescod, D. J., Daire, A. P., Dagley, M. A., \& Young, C. Y. (2017). Predicting undergraduate student retention in STEM majors based on career development factors. The Career Development Quarterly, 65(1), 88-93. doi:10.1002/cdq.12082

Bipp, T., Kleingeld, A., \& van Dam, K. (2017). Approach and avoidance temperament: An examination of its construct and predictive validity at work. European Journal of Psychological Assessment, 33(3), 196-206. doi:10.1027/1015-5759/a000285

Blustein, D. L., Ellis, M. V., \& Devenis, L. E. (1989). The development and validation of a two-dimensional model of the commitment to career choices process. Journal of Vocational Behavior, 35(3), 342-378. doi:10.1016/0001-8791(89)90034-1

Borges, N. J., Richard, G. V., \& Duffy, R. D. (2007). Career maturity of students in accelerated versus traditional programs. The Career Development Quarterly, 56(2), 171-176. doi:10.1002/j.2161-0045.2007.tb00029.x

Bum, C. H., \& Lee, K. (2018). The relationships between professors' super-leadership, selfleadership, and career preparation behavior in college students. Sport Mont, 16(2), 3944. doi:10.26773/smj.180607

Busacca, L. A., \& Taber, B. J. (2002). The Career maturity inventory-revised: A preliminary psychometric investigation. Journal of Career Assessment, 10(4), 441-455. doi:10.1177/1069072702238406 
Buyukgoze-Kavas, A. (2016). Predicting career adaptability from positive psychological traits. Career Development Quarterly, 64(2), 114-125. doi:10.1002/cdq.12045

Buyukgoze-Kavas, A. (2014). Validation of the Career Adapt-Abilities Scale-Turkish form and its relation to hope and optimism. Australian Journal of Career Development, 23, 125-132. doi: 10.1177/1038416214531931

Cabras, C., \& Mondo, M. (2018). Future orientation as a mediator between career adaptability and life satisfaction in university students. Journal of Career Development, 45(6), 597-609. doi:10.1177/0894845317727616

Cai, Z., Guan, Y., Li, H., Shi,W., Guo, K., Liu, Y., Li, Q., Han, X., Jiang, P., Fang, Z. \& Hua, H. (2015). Self-esteem and proactive personality as predictors of future work self and career adaptability: An examination of mediating and moderating processes. Journal of Vocational Behavior, 86, 86-94. doi: 10.1016/j.jvb.2014.10.004

Cardoso, P., Gonçalves, M. M., Duarte, M. E., Silva, J. R., \& Alves, D. (2016). Life Design Counseling outcome and process: A case study with an adolescent. Journal of Vocational Behavior, 93, 58-66. doi:10.1016/j.jvb.2016.01.002

Cardoso, P., Janeiro, I. N., \& Duarte, M. E. (2018). Life Design Counseling group intervention with portuguese adolescents: A process and outcome study. Journal of Career Development, 45(2), 183-196. doi:10.1177/0894845316687668

Caza, A., Brower, H. H., \& Wayne, J. H. (2015). Effects of a holistic, experiential curriculum on business students' satisfaction and career confidence. The International Journal of Management Education, 13(1), 75-83. doi:10.1016/j.ijme.2015.01.006

Celik, P., \& Storme, M. (2018). Trait emotional intelligence predicts academic satisfaction through career adaptability. Journal of Career Assessment, 26(4), 666-677. doi:10.1177/1069072717723290

Chan, K. Y., Uy, M. A., Moon-ho, R. H., Sam, Y. L., Chernyshenko, O. S., \& Yu, K. Y. T. (2015). Comparing two career adaptability measures for career construction theory: Relations with boundaryless mindset and protean career attitudes. Journal of Vocational Behavior, 87, 22-31. doi:10.1016/j.jvb.2014.11.006

Chen, S., \& Zhou, K. (2018). Career planning decision-making of college students based on cognitive science. NeuroQuantology, 16(6), 487-493. doi:10.14704/nq.2018.16.6.1662

Chen, Z., Solberg, S., \& Ye, A. (2018). Chinese youth career adaptability: contextual influences and pathways to positive youth development. Youth and Society. doi:10.1177/0044118X18784058

Cheng, C., Yang, L., Chen, Y., Zou, H., Su, Y., \& Fan, X. (2016). Attributions, future time perspective and career maturity in nursing undergraduates: Correlational study design. BMC medical education, 16(1), 26. doi:10.1186/s12909-016-0552-1

Cheung, R., \& Jin, Q. (2015). Impact of a career exploration course on career decision making, adaptability, and relational support in Hong Kong. Journal of Career Assessment, 24(3), 481-496. doi:10.1177/1069072715599390

Chi, J., Leuty, M. E., Bullock-Yowell, E., \& Dahlen, E. R. (2018). Work value differentiation and profile elevation: What do they predict? Journal of Career Assessment. doi:10.1177/1069072718813368

Chishima, Y., Murakami, T., Worrell, F. C., \& Mello, Z. R. (2019). The Japanese version of the Adolescent Time Inventory-Time Attitudes (ATI-TA) Scale: Internal consistency, structural validity, and convergent validity. Assessment, 26(2), 181-192.

Choi, K., \& Kim, D.-Y. (2013). A cross cultural study of antecedents on career preparation behavior: Learning motivation, academic achievement, and career decision selfefficacy. Journal of Hospitality, Leisure, Sport \& Tourism Education, 13, 19-32. doi:10.1016/j.jhlste.2013.04.00

Choi, S., Hutchison, B., Lemberger, M. E., \& Pope, M. (2012). A longitudinal study of the developmental trajectories of parental attachment and career maturity of South Korean 
adolescents. The Career Development Quarterly, 60(2), 163-177. doi:10.1002/j.21610045.2012.00014.X

Chong, S., \& Leong, F. T. L. (2017). Antecedents of career adaptability in strategic career management. Journal of Career Assessment, 25(2), 268-280. doi:10.1177/1069072715621522

Chui, Y. H. (2012). Psychometric report on career readiness scale. Hong Kong: Hong Kong Sheng Kung Hui Welfare Council.

Clair, R. S., Hutto, T., MacBeth, C., Newstetter, W., McCarty, N. A., \& Melkers, J. (2017). The "new normal": Adapting doctoral trainee career preparation for broad career paths in science. PloS one, 12(5), e0177035. doi:10.1371/journal.pone.0177035

Coetzee, M., \& Beukes, C. J. (2010). Employability, emotional intelligence and career preparation support satisfaction among adolescents in the school-to-work transition phase. Journal of Psychology in Africa, 20(3), 439-446. doi:10.1080/14330237.2010.10820396

Corr, P. J., \& Mutinelli, S. (2017). Motivation and young people's career planning: A perspective from the reinforcement sensitivity theory of personality. Personality and Individual Differences, 106, 126-129. doi:10.1016/j.paid.2016.10.043

Creed, P. A., \& Hennessy, D. A. (2016). Evaluation of a goal orientation model of vocational identity. Career Development Quarterly, 64(4), 345-359. doi:10.1002/cdq.12070

Creed, P., Prideaux, L.-A., \& Patton, W. (2005). Antecedents and consequences of career decisional states in adolescence. Journal of Vocational Behavior, 67(3), 397-412. doi:10.1016/j.jvb.2004.08.008

Creed, P. A., \& Patton, W. (2003). Predicting two components of career maturity in school based adolescents. Journal of Career Development, 29(4), 277-290. doi:10.1023/a:1022943613644

Creed, P. A., Patton, W., \& Bartrum, D. (2002). Multidimensional properties of the LOT-R: Effects of optimism and pessimism on career and well-being related variables in adolescents. Journal of Career Assessment, 10(1), 42-61.

Creed, P. A., Patton, W., \& Prideaux, L.-A. (2007). Predicting change over time in career planning and career exploration for high school students. Journal of Adolescence, 30(3), 377-392. doi:10.1016/j.adolescence.2006.04.003

Crites, J. (1971). The maturity of vocational attitudes in adolescence Vocational Guidance Quarterly, 20(1), 82-82. doi:10.1002/j.2164-585X.1971.tb02014.x

de Guzman, A. B., \& Choi, K. O. (2013). The relations of employability skills to career adaptability among technical school students. Journal of Vocational Behavior, 82, 199-207. doi:10.1016/j.jvb.2013.01.009

Di Fabio, A., \& Kenny, M. E. (2012). Emotional intelligence and perceived social support among Italian high school students. Journal of Career Development, 39(5), 461-475. doi:10.1177/0894845311421005

Di Fabio, A., \& Kenny, M. E. (2016). From decent work to decent lives: Positive self and relational management (PS\&RM) in the twenty-first century. Frontiers in Psychology, 7, 1-12. doi:10.3389/fpsyg.2016.00361.

Dipeolu, A., Deutch, S., Hargrave, S., \& Storlie, C. A. (2019). Developmentally relevant career constructs: Response patterns of youth with ADHD and LDs. Canadian Journal of Career Development, 18(1), 45-56.

Dipeolu, A., Sniatecki, J. L., Storlie, C. A., \& Hargrave, S. (2013). Dysfunctional career thoughts and attitudes as predictors of vocational identity among young adults with attention deficit hyperactivity disorder. Journal of Vocational Behavior, 82(2), 79-84. doi:10.1016/j.jvb.2013.01.003

Dipeolu, A. O., Hargrave, S., Sniatecki, J. L., \& Donaldson, J. (2012). Improving prediction of significant career-related constructs for high school students with learning 
disabilities. The Career Development Quarterly, 60(3), 207-220. doi:10.1002/j.21610045.2012.00017.x

Douglass, R. P., \& Duffy, R. D. (2014). Calling and career adaptability among undergraduate students. Journal of Vocational Behavior, 86, 58-65. doi:10.1016/j.jvb.2014.11.003

Douglass, R. P., Velez, B. L., Conlin, S. E., Duffy, R. D., \& England, J. W. (2017).

Examining the Psychology of working theory: Decent work among sexual minorities. Journal of Counseling Psychology, 64(5), 550-559. doi:10.1037/cou0000212

Duffy, R. D. (2010). Sense of control and career adaptability among undergraduate students. Journal of Career Assessment, 18, 420-430. doi:10.1177/1069072710374587

Dumulescu, D., Balazsi, R., \& Opre, A. (2015). Calling and career competencies among Romanian students: The mediating role of career adaptability. Procedia - Social and Behavioral Sciences, 209, 25-32. doi:10.1016/j.sbspro.2015.11.223.

Dumulescu, D., Filip, C., \& Opre, A. (2015). Career calling: Correlates in a Romanian student sample. Cognition, Brain, Behavior, 19(3), 271-284. doi:10.1016/j.sbspro.2015.11.223

Dybwad, T. E. (2008). The structural validity of daidalos: A measure of career maturity. Scandinavian Journal of Educational Research, 52(2), 135-152. doi:10.1080/00313830801915762

Dybwad, T. E. (2009). Career maturity: A latent means and covariance structure analysis of Daidalos. Scandinavian Journal of Psychology, 50(2), 109-120. doi:10.1111/j.14679450.2008.00702.x

Ebenehi, A. S., Rashid, A. M., \& Bakar, A. R. (2016). Predictors of career adaptability skill among higher education students in Nigeria. International Journal for Research in Vocational Education and Training, 3(3), 212-229.

Einarsdóttir, S., Vilhjàlmsdottir, G., Smaradottir, S. B., \& Kjartansdottir, B. (2015). A culture sensitive approach in the development of the Career Adapt-Abilities Scale in Iceland: Theoretical and operational considerations. Journal of Vocational Behavior, 89, 172181. doi:10.1016/j.jvb. 2015.06.006

Eryilmaz, A., \& Kara, A. (2018). Investigation of the effectiveness of a career adaptability program for prospective counsellors. Current Psychology, 1-9. doi:10.1007/s12144018-9827-5

Fan, J. (2016). The role of thinking styles in career decision-making self-efficacy among university students. Thinking Skills and Creativity, 20, 63-73. doi:10.1016/j.tsc.2016.03.001

Fan, W., Cheung, F. M., Leong, F. T. L., \& Cheung, S. F. (2014). Contributions of family factors to career readiness: A cross-cultural comparison. The Career Development Quarterly, 62(3), 194-209. doi:10.1002/j.2161-0045.2014.00079.x

Fang, W. J., Zhang, Y. T., Mei, J. J., Chai, X. H., \& Fan, X. Z. (2018). Relationships between optimism, educational environment, career adaptability and career motivation in nursing undergraduates: A cross-sectional study. Nurse Education Today, 68, 33-39. doi:10.1016/j.nedt.2018.05.025

Fetherston, M. (2019). What influences college students' career information seeking on the internet? A test of the comprehensive model of information seeking. Journal of Applied Communication Research. doi:10.1080/00909882.2019.1615631

Fetherston, M., Cherney, M. R., \& Bunton, T. E. (2018). Uncertainty, technology use, and career preparation self-efficacy. Western Journal of Communication, 82(3), 276-295. doi:10.1080/10570314.2017.1294704

Flouri, E., \& Buchanan, A. (2002). The role of work-related skills and career role models in adolescent career maturity. The Career Development Quarterly, 51(1), 36-43. doi:10.1002/j.2161-0045.2002.tb00590.x 
Foster, J., \& Yaoyuneyong, G. (2014). Collaborative cross-disciplinary client-based projects: A case study. International Journal of Fashion Design, Technology and Education, 7(3), 154-162. doi:10.1080/17543266.2014.937832

Fouad, N. A., Ghosh, A., Wen-hsin, C., Figueiredo, C., \& Bachhuber, T. (2016). Career exploration among college students. Journal of College Student Development, 57(4), 460-464.

Foundation, C. F. (2013). Casey life skills. Retrieved from https://www.casey.org/casey lifeskills-resources/

Gaffner, D. C., \& Hazler, R. J. (2002). Factors related to indecisiveness and career indecision in undecided college students. Journal of College Student Development, 43(3), 317326.

Gamboa, V., Paixao, M. P., \& de Jesus, S. N. (2014). Vocational profiles and internship quality among Portuguese VET students. International Journal for Educational and Vocational Guidance, 14, 1-24. doi:10.1007/s10775-014-9268-0

Garcia, P., Restubog, S. L. D., Ocampo, A. C., Wang, L., \& Tang, R. L. (2019). Role modeling as a socialization mechanism in the transmission of career adaptability across generations. Journal of Vocational Behavior, 111, 39-48. doi:10.1016/j.jvb.2018.12.002

Gati, I., \& Osipow, S. (2000). Career Decision Making Difficulties Questionnaire Revised. Retrieved from Retrieved from http://kivunim.huji.ac.il/cddq/

Ghosh, A., \& Fouad, N. A. (2017). Career adaptability and social support among graduating college seniors. Career Development Quarterly, 65(3), 278-283. doi:10.1002/cdq. 12098

Ginevra, M. C., Annovazzi, C., Santilli, S., Di Maggio, I., \& Camussi, E. (2018). Breadth of vocational interests: The role of career adaptability and future orientation. The Career Development Quarterly, 66(3), 233-245. doi:10.1002/cdq.12145

Ginevra, M. C., Magnano, P., Lodi, E., Annovazzi, C., Camussi, E., Patrizi, P., \& Nota, L. (2018). The role of career adaptability and courage on life satisfaction in adolescence. Journal of Adolescence, 62, 1-8. doi:10.1016/j.adolescence.2017.11.002

Ginevra, M. C., \& Nota, L. (2018). 'Journey in the world of professions and work': A career intervention for children. The Journal of Positive Psychology, 13(5), 460-470. doi:10.1080/17439760.2017.1303532

Ginevra, M. C., Pallini, S., Vecchio, G. M., Nota, L., \& Soresi, S. (2016). Future orientation and attitudes mediate career adaptability and decidedness. Journal of Vocational Behavior, 95-96, 102-110. doi:10.1016/j.jvb.2016.08.003

Ginevra, M. C., Sgaramella, T. M., Ferrari, L., Nota, L., Santilli, S., \& Soresi, S. (2017). Visions about future: a new scale assessing optimism, pessimism, and hope in adolescents. International Journal for Educational and Vocational Guidance, 17(2), 187-210. doi:10.1007/s10775-016-9324-z

Gordon, L., \& Meyer, J. C. (2002). Career indecision amongst prospective university students. South African Journal of Psychology, 32(4), 41-47. doi:10.1177/008124630203200405

Guan, M., Capezio, A., Restubog, S. L. D., Read, S., Lajom, J. A. L., \& Li, M. (2016). The role of traditionality in the relationships among parental support, career decisionmaking self-efficacy and career adaptability. Journal of Vocational Behavior, 94, 114-123. doi:10.1016/j.jvb.2016.02.018.

Guan, Y. J., Dai, X., Gong, Q., Deng, Y. F., Hou, Y. S., Dong, Z. L., Wang, L. H., Huang, Z., \& Lai, X. (2017). Understanding the trait basis of career adaptability: A two-wave mediation analysis among Chinese university students. Journal of Vocational Behavior, 101, 32-42. doi:10.1016/j.jvb.2017.04.004 
Guan, Y., Deng, H., Sun, J., Wang, Y., Cai, Z., Ye, L., ... Li, Y. (2013). Career adaptability, job search self-efficacy and outcomes: A three-wave investigation among Chinese university graduates. Journal of Vocational Behavior, 83, 561-570. doi:10.1016/j.jvb.2013.09.003

Guan, Y., Guo, Y., Bond, M. H., Cai, Z., Zhou, X., Xu, J., ... Ye, L. (2014). New job market entrants' future work self, career adaptability and job search outcomes: Examining mediating and moderating models. Journal of Vocational Behavior, 85, 136-145. doi:10.1016/j.jvb.2014.05.003

Guan, Y. J., Liu, S. M., Guo, M. J., Li, M. Y., Wu, M. Y., Chen, S. X., Xu, S. L., \& Tian, L. (2018). Acculturation orientations and Chinese student Sojourners' career adaptability: The roles of career exploration and cultural distance. Journal of Vocational Behavior, 104, 228-239. doi:10.1016/j.jvb.2017.11.008

Guan, Y., Wang, Z., Gong, Q., Cai, Z., Xu, S. L., Xiang, Q., . . Tian, L. (2018). Parents' career values, adaptability, career-specific parenting behaviors, and undergraduates' career adaptability. The Counseling Psychologist, 46(7), 922-946. doi:10.1177/0011000018808215

Guan, Y., Wang, F., Liu, H., Ji, Y., Jia, X., Fang, Z., ... Li, C. (2015). Career-specific parental behaviors, career exploration and career adaptability: A three-wave investigation among Chinese undergraduates. Journal of Vocational Behavior, 86, 95-103. doi:10.1016/j.jvb.2014.10.007

Guan, Y. J., Zhuang, M. K., Cai, Z. J., Ding, Y. C., Wang, Y., Huang, Z., \& Lai, X. (2017). Modeling dynamics in career construction: Reciprocal relationship between future work self and career exploration. Journal of Vocational Behavior, 101, 21-31. doi:10.1016/j.jvb.2017.04.003

Gunkel, M., Schlaegel, C., Langella, I. M., \& Peluchette, J. V. (2010). Personality and career decisiveness: An international empirical comparison of business student's career planning. Personnel Review, 39, 503-524. doi:10.1108/00483481011045443

Guo, Y., Guan, Y., Yang, X., Xu, J., Zhou, X., She, Z., ... Fu, M. (2014). Career adaptability, calling and the professional competence of social work students in China: A career construction perspective. Journal of Vocational Behavior, 85, 394-402. doi:10.1016/j.jvb.2014.09.001

Hamtiaux, A., Houssemand, C., \& Vrignaud, P. (2013). Individual and career adaptability: Comparing models and measures. Journal of Vocational Behavior, 83, 130-141. doi:10.1016/j.jvb.2013.03.006

Han, J., \& Lee, K. (1997). A study on the validation of career attitude maturity inventory. The Journal of Career Educational Research, 8, 219-255.

Han, H., \& Rojewski, J. W. (2015). Gender-specific models of work-bound Korean adolescents' social supports and career adaptability on subsequent job satisfaction. Journal of Career Development, 42, 149-164. doi:10.1177/0894845314545786

Hardin, E. E., \& Leong, F. T. (2004). Decision-making theories and career assessment: A psychometric evaluation of the decision making inventory. Journal of Career Assessment, 12(1), 51-64. doi:10.1177/1069072703257730

Hardré, P. L., \& Hackett, S. M. (2015). Understanding the graduate college experience: perceptual differences by degree type, point-in-program and disciplinary subgroups. Learning Environments Research, 18(3), 453-468. doi:10.1007/s10984-015-9194-1

Harlow, A. J., \& Bowman, S. L. (2016). Examining the career decision self-efficacy and career maturity of community college and first-generation students. Journal of Career Development, 43(6), 512-525. doi:10.1177/0894845316633780

Henry, P. (2003). Toward a career development model for postbaccalaureate premedical programs: From theory to practice. Psychological Reports, 93(2), 335-342. doi:10.2466/pr0.2003.93.2.335 
Heo, G., \& Kim, T. (2016). Autoregressive cross-lagged modeling of the reciprocal longitudinal relationship between self-esteem andcareer maturity. Journal of Career Development, 43(3), 273-288. doi:10.1177/0894845315598002

Hiller, M. L., Salvatore, C., \& Taniguchi, T. (2014). Evaluation of a criminal justice internship program: Why do students take it and does it improve career preparedness? Journal of Criminal Justice Education, 25(1), 1-15. doi:10.1080/10511253.2013.856929

Hirschi, A. (2009). Career adaptability development in adolescence: Multiple predictors and effect on sense of power and life satisfaction. Journal of Vocational Behavior, 74, 145-155. doi:10.1016/j.jvb. 2009.01.002

Hirschi, A. (2010a). Individual predictors of adolescents' vocational interest stabilities. International Journal for Educational and Vocational Guidance, 10(1), 5-19. doi:10.1007/s10775-009-9171-2

Hirschi, A. (2010b). The role of chance events in the school-to-work transition: The influence of demographic, personality and career development variables. Journal of Vocational Behavior, 77(1), 39-49. doi:10.1016/j.jvb.2010.02.002

Hirschi, A. (2010c). Swiss adolescents' career aspirations: Influence of context, age, and career adaptability. Journal of Career Development, 36, 228-245. doi:10.1177/0894845309345844

Hirschi, A. (2014). Hope as a resource for self-directed career management: Investigating mediating effects on proactive career behaviors and life and job satisfaction. Journal of Happiness Studies, 15, 1495-1515. doi: 10.1007/s10902-013-9488-x

Hirschi, A., \& Herrmann, A. (2013). Calling and career preparation: Investigating developmental patterns and temporal precedence. Journal of Vocational Behavior, 83(1), 51-60. doi:10.1016/j.jvb.2013.02.008

Hirschi, A., Herrmann, A., \& Keller, A. C. (2015). Career adaptivity, adaptability, and adapting: A conceptual and empirical investigation. Journal of Vocational Behavior, 87, 1-10. doi:10.1016/j.jvb.2014.11.008

Hirschi, A., \& Läge, D. (2007). The relation of secondary students' career-choice readiness to a six-phase model of career decision making. Journal of Career Development, 34(2), 164-191. doi:10.1177/0894845307307473

Hirschi, A., Niles, S. G., \& Akos, P. (2011). Engagement in adolescent career preparation: Social support, personality and the development of choice decidedness and congruence. Journal of Adolescence, 34(1), 173-182. doi:10.1016/j.adolescence.2009.12.009

Hirschi, A., \& Valero, D. (2015). Career adaptability profiles and their relationship to adaptivity and adapting. Journal of Vocational Behavior, 88, 220-229. doi:10.1016/j.jvb.2015.03.010

Hirschi, A., \& Vondracek, F. W. (2009). Adaptation of career goals to self and opportunities in early adolescence. Journal of Vocational Behavior, 75(2), 120-128. doi:10.1016/j.jvb.2009.05.005

Holland, J. L., Daiger, D. C., \& Power, P. G. (1980). My vocational situation. Sunnyville, CA: Consulting Psychologists Press, Incorporated.

Hollman, A. K., Hollman, T. J., Shimerdla, F., Bice, M. R., \& Adkins, M. (2019). Information technology pathways in education: Interventions with middle school students. Computers \& Education, 135, 49-60. doi:10.1016/j.compedu.2019.02.019

Hou, C., Wu, L., \& Liu, Z. (2014). Effect of proactive personality and decision-making selfefficacy on career adaptability among Chinese graduates. Social Behaviour and Personality, 42, 903-912. doi:10.2224/sbp. 2014.42.6.903 
Hou, Z. J., Leung, S. A., Li, X., Li, X., \& Xu, H. (2012). Career Adapt-Abilities ScaleChina Form: Construction and initial validation. Journal of Vocational Behavior, 80, 686-691. doi:10.1016/j.jvb.2012. 01.006

Huang, S. M. (2001). The relationship among self-efficacy, career motivation, and career maturity for students of the Normal College (Unpublished Thesis). Taiwan.

Hughes, C. (2011). The influence of self-concept, parenting style and individualismcollectivism on career maturity in Australia and Thailand. International Journal for Educational and Vocational Guidance, 11(3), 197-210. doi:10.1007/s10775-0119208-1

Hughes, C., \& Thomas, T. (2006). Adapting the Career Development Inventory-Australia for cross-cultural research. Journal of Vocational Behavior, 69(2), 276-288. doi:10.1016/j.jvb.2006.05.008

Hui, T., Yuen, M., \& Chen, G. W. (2018a). Career-Related filial piety and career adaptability in Hong Kong university students. Career Development Quarterly, 66(4), 358-370. doi:10.1002/cdq.12156

Hui, T., Yuen, M., \& Chen, G. W. (2018b). Career adaptability, self-esteem, and social support among Hong Kong university students. Career Development Quarterly, 66(2), 94-106. doi:10.1002/cdq.12118

Hummel, H. G. K., Boyle, E. A., Einarsdóttir, S., Pétursdóttir, A., \& Graur, A. (2018). Gamebased career learning support for youth: effects of playing the Youth@Work game on career adaptability. Interactive Learning Environments, 26(6), 745-759. doi:10.1080/10494820.2017.1402062

Hummel, H. G. K., Boyle, E. A., Einarsdóttir, S., Pétursdóttir, A., \& Graur, A. (2017). Gamebased career learning support for youth: effects of playing the Youth@Work game on career adaptability. Interactive Learning Environments, 1-15. doi:10.1080/10494820.2017.1402062

Hur, Y., Cho, A. R., Song, E. J., \& Kim, S. (2018). Evaluation of a systematic career coaching program for medical students in Korea using the Career Readiness Inventory. Journal of educational evaluation for health professions, 15, 9. doi:10.3352/jeehp.2018.15.10

Isik, E., Yegin, F., Koyuncu, S., Eser, A., Comlekciler, F., \& Yildirim, K. (2018). Validation of the Career Adapt-Abilities Scale-Short Form across different age groups in the Turkish context. International Journal for Educational and Vocational Guidance, 18(3), 297-314. doi:10.1007/s10775-018-9362-9

Ismail, S. (2017). Graduate employability capacities, self-esteem and career adaptability among South African young adults. SA Journal of Industrial Psychology, 43(1). doi:10.4102/sajip.v43i0.1396

Ismail, S., Ferreira, N., \& Coetzee, M. (2016). Young emerging adults' graduateness and career adaptability: Exploring the moderating role of self-esteem. Journal of Psychology in Africa, 26(1), 1-10. doi:10.1080/14330237.2016.1148417.

İspir, Ö., Elibol, E., \& Sönmez, B. (2019). The relationship of personality traits and entrepreneurship tendencies with career adaptability of nursing students. Nurse Education Today, 79, 41-47. doi:10.1016/j.nedt.2019.05.017

Jaensch, V. K., Hirschi, A., \& Spurk, D. (2016). Relationships of vocational interest congruence, differentiation, and elevation to career preparedness among university students. Zeitschrift für Arbeits- und Organisationspsychologie A\&O, 60(2), 79-89. doi:10.1026/0932-4089/a000210

Janeiro, I. N. (2010). Motivational dynamics in the development of career attitudes among adolescents. Journal of Vocational Behavior, 76(2), 170-177.

doi:10.1016/j.jvb.2009.12.003 
Janeiro, I. N., \& Marques, J. F. (2010). Career coping styles: Differences in career attitudes among secondary school students. International Journal for Educational and Vocational Guidance, 10(1), 35-48. doi:10.1007/s10775-009-9170-3

Janeiro, I. N., Mota, L. P., \& Ribas, A. M. (2014). Effects of two types of career interventions on students with different career coping styles. Journal of Vocational Behavior, 85, 115-124. doi:10.1016/j.jvb.2014. 05.006

Jang, S. M., Lim, D. S., \& Song, B. K. (1992). A study on the standardization of the career maturity inventory. Korean Educational Development Institute. Seoul, Korea.

Jawarneh, M. (2016). Career maturity among university students in Jordan: The case for social studies. Australian Journal of Career Development, 25(3), 110-116. doi:10.1177/1038416216676807

Jiang, Z., Hu, X., Wang, Z., \& Jiang, X. (2017). Career decision self-efficacy and life satisfaction in China: An empirical analysis. Social Indicators Research, 132(1), 137154. doi:10.1007/s11205-015-1201-5

Jo, Y. G., Moon, K. S., \& Yang, C. H. (2018). Correlations relationship between social support and career decision-making attitudes of college Taekwondo athletes. Journal of Engineering and Applied Sciences, 13(Specialissue2), 3037-3041. doi:10.3923/jeasci.2018.3037.3041

Johnson, S. L., Tandon, S. D., \& Cheng, T. L. (2015). Career readiness: A potential pathway through which urban youth exposure to stress influences adult health. Journal of Community Psychology, 43(3), 321-337. doi:10.1002/jcop.21681

Jordan, S., Gessnitzer, S., \& Kauffeld, S. (2017). Develop yourself, develop others? How coaches and clients benefit from train-the-coach courses. Coaching, 10(2), 125-139. doi:10.1080/17521882.2017.1330353

Karacan-Ozdemir, N. (2019). Associations between career adaptability and career decisionmaking difficulties among Turkish high school students. International Journal for Educational and Vocational Guidance. doi:10.1007/s10775-019-09389-0

Karacan-Ozdemir, N., \& Guneri, O. Y. (2017). the factors contribute to career adaptability of high-school students. Eurasian Journal of Educational Research(67), 183-198. doi:10.14689/ejer.2017.67.11

Keller, B. K., \& Whiston, S. C. (2008). The role of parental influences on young adolescents' career development. Journal of Career Assessment, 16(2), 198-217. doi:10.1177/1069072707313206

Kim, Y., Ju, E., Rosenberg, R., \& Farmer, E. M. Z. (2019). Estimating the effects of independent living services on educational attainment and employment of foster care youth. Children and Youth Services Review, 96, 294-301. doi:10.1016/j.childyouth.2018.11.048

Kim, B., Jung, S. H., Jang, S. H., Lee, B., Rhee, E., Cho, S. H., \& Lee, S. M. (2014). Construction and initial validation of the planned happenstance career inventory. The Career Development Quarterly, 62(3), 239-253. doi:10.1002/j.21610045.2014.00082.x

Kim, S. K., Min, K. H., \& Yang, C. H. (2018). Relationships of social support perceived by college Taekwondo athletes with career preparation behavior and career exploration behavior. Journal of Engineering and Applied Sciences, 13(Specialissue2), 2828-2833. doi:10.3923/jeasci.2018.2828.2833

Kim, K.-N., \& Oh, S.-H. (2013). Effects of social constraints on career maturity: The mediating effect of the time perspective. Asia Pacific Education Review, 14(2), 221229. doi:10.1007/s12564-013-9240-6

Kim, N. R., \& Lee, K. H. (2018). the effect of internal locus of control on career adaptability: The mediating role of career decision-making self-efficacy and occupational engagement. Journal of Employment Counseling, 55(1), 2-15. doi:10.1002/joec. 12069 
Kim, S.-y., Ahn, T., \& Fouad, N. (2016). Family influence on Korean students' career decisions. Journal of Career Assessment, 24(3), 513-526. doi:10.1177/1069072715599403

Kirdök, O., \& Bölükbasi., A. (2018). The role of senior university students' career adaptability in predicting their subjective well-being. Journal of Education and Training Studies, 6(5), 47-54.

Kiuru, N., Koivisto, P., Mutanen, P., Vuori, J., \& Nurmi, J.-E. (2011). How do efforts to enhance career preparation affect peer groups? Journal of Research on Adolescence, 21(3), 677-690. doi:10.1111/j.1532-7795.2010.00701.x

Kleiman, T., Gati, I., Peterson, G., Sampson, J., Reardon, R., \& Lenz, J. (2004). Dysfunctional thinking and difficulties in career decision making. Journal of Career Assessment, 12(3), 312-331. doi:10.1177/1069072704266673

Klier, J., Klier, M., Thiel, L., \& Agarwal, R. (2019). Power of mobile peer groups: A design-oriented approach to address youth unemployment. Journal of Management Information Systems, 36(1), 158-193. doi:10.1080/07421222.2018.1550557

Koen, J., Klehe, U. C., \& Van Vianen, A. E. (2012). Training career adaptability to facilitate a successful school-to-work transition. Journal of Vocational Behavior, 81, 395-408. doi:10.1016/j.jvb.2012.10.003

Koivisto, P., Vinokur, A. D., \& Vuori, J. (2011). Effects of career choice intervention on components of career preparation. The Career Development Quarterly, 59(4), 345366. doi:10.1002/j.2161-0045.2011.tb00074.x

Konstam, V., Celen-Demirtas, S., Tomek, S., \& Sweeney, K. (2015). Career adaptability and subjective wellbeing in unemployed emerging adults: A promising and cautionary tale. Journal of Career Development, 42(6), 463-477. doi:10.1177/0894845315575151

Kornspan, A. S., \& Etzel, E. F. (2001). The relationship of demographic and psychological variables to career maturity of junior college student-athletes. Journal of College Student Development, 42(2), 122-132.

Koys, D. J. (2017). Using the Department of Labor's "My Next Move" to improve career preparedness. Journal of Management Education, 41(1), 94-117. doi:10.1177/1052562916670195

Kracke, B. (2001). Berufsbezogene exploration im jugendalter [Vocational exploration in adolescence]. University of Mannheim, Mannheim.

Kustanti, E. R., Resdasari, A., Ratnaningsih, I. Z., \& Fauziah, N. (2018). "Enhance Your Strength": A training models to increase career maturity among vocational student. Advanced Science Letters, 24(6), 4269-4272. doi:10.1166/as1.2018.11586

Kwok, L., Adams, C. R., \& Feng, D. (2012). A comparison of graduating seniors who receive job offers and those who do not according to hospitality recruiters' selection criteria. International Journal of Hospitality Management, 31(2), 500-510. doi:10.1016/j.ijhm.2011.07.008

Lapan, R. T., Poynton, T., Marcotte, A., Marland, J., \& Milam, C. M. (2017). College and career readiness counseling support scales. Journal of Counseling \& Development, 95(1), 77-86. doi:10.1002/jcad.12119

Lazarides, R., Rohowski, S., Ohlemann, S., \& Ittel, A. (2016). The role of classroom characteristics for students' motivation and career exploration. Educational Psychology, 36(5), 992-1008. doi:10.1080/01443410.2015.1093608

Lee, H.-Y., \& Hughey, K. F. (2001). The relationship of psychological separation and parental attachment to the career maturity of college freshmen from intact families Journal of Career Development, 27(4), 279-293. doi:10.1177/089484530102700404

Lee, I. H., Rojewski, J. W., \& Hill, R. B. (2013). Classifying Korean adolescents' career preparedness. International Journal for Educational and Vocational Guidance, 13(1), 25-45. doi:10.1007/s10775-012-9236-5 
Lee, K.-H. (2001). A cross-cultural study of the career maturity of Korean and United States high school students. Journal of Career Development, 28(1), 43-57. doi:10.1177/089484530102800104

Lee, S.-A., Lee, H.-S., Song, H.-S., \& Kim, S.-G. (2015). The relationship between attachment and career maturity: The mediating role of self-efficacy. International Social Work, 58(1), 153-164. doi:10.1177/0020872812456053

Lee, S. H., Lee, S. M., \& Yu, K. (2008). A typology of career barriers. Asia Pacific Education Review, 9(2), 157-167. doi:10.1007/BF03026496

Lever, N., Sander, M. A., Lombardo, S., Randall, C., Axelrod, J., Rubenstein, M., \& Weist, M. D. (2004). A drop-out prevention program for high-risk inner-city youth. Behavior Modification, 28(4), 513-527. doi:10.1177/0145445503259520

Li, Y., Guan, Y., Wang, F., Zhou, X., Guo, K., Jiang, P., ... Fang, Z. (2015). Big five personality and BIS/BAS traits as predictors of career explorations: The mediation role of career adaptability. Journal of Vocational Behavior, 89, 39-45. doi:10.1016/j.jvb.2015.04.006

Lim, J. Y., Kim, M. A., Kim, S. Y., Kim, E. J., Lee, J. E., \& Ko, Y. K. (2010). The effects of a cognitive-behavioral therapy on career attitude maturity, decision making style, and self-esteem of nursing students in Korea. Nurse Education Today, 30(8), 731-736. doi:10.1016/j.nedt.2010.01.014

Lim, S. A., \& You, S. (2019). Long-Term effect of parents' support on adolescents' career maturity. Journal of Career Development, 46(1), 48-61. doi:10.1177/0894845317731866

Lindstrom Johnson, S., Jones, V., \& Cheng, T. (2014). Promoting successful transition to adulthood for urban youths: Are risk behaviors associated with career readiness? Social Work Research, 38(3), 144-153. doi:10.1093/swr/svu020

Lindstrom Johnson, S., Jones, V., \& Cheng, T. L. (2015). Promoting "Healthy Futures" to reduce risk behaviors in urban youth: A randomized controlled trial. American Journal of Community Psychology, 56(1-2), 36-45. doi:10.1007/s10464-015-9734-y

Lindstrom Johnson, S., Pas, E., \& Bradshaw, C. P. (2016). Understanding the association between school climate and future orientation. Journal of Youth and Adolescence, 45(8), 1575-1586. doi:10.1007/s10964-015-0321-1

Liptak, J. J. (2008). Career planning scale. Indianapolis, IN: Jist Works.

Lombardi, A., Seburn, M., \& Conley, D. (2011). Development and initial validation of a measure of academic behaviors associated with college and career readiness. Journal of Career Assessment, 19(4), 375-391. doi:10.1177/1069072711409345

Lombardi, A. R., Conley, D. T., Seburn, M. A., \& Downs, A. M. (2013). College and career readiness assessment: Validation of the key cognitive strategies framework. Assessment for Effective Intervention, 38(3), 163-171. doi: $10.1177 / 1534508412448668$

Lundberg, C. A. (2014). Peers and faculty as predictors of learning for community college students. Community College Review, 42(2), 79-98. doi:10.1177/0091552113517931

Lusk, S. L., \& Cook, D. (2009). Enhancing career exploration, decision making, and problem solving of adolescent girls with disabilities. Journal of Vocational Rehabilitation, 31(3), 145-153. doi:10.3233/JVR-2009-0484

Maree, J. G. (2019). Group career construction counseling: A mixed-methods intervention study with high school students. Career Development Quarterly, 67(1), 47-61. doi:10.1002/cdq. 12162

Maree, J. G., Cook, A. V., \& Fletcher, L. (2018). Assessment of the value of group-based counselling for career construction. International Journal of Adolescence and Youth, 23(1), 118-132. doi:10.1080/02673843.2017.1309324

Maree, J. G., Pienaar, M., \& Fletcher, L. (2018). Enhancing the sense of self of peer 
supporters using life design-related counselling. South African Journal of Psychology, 48(4), 420-433. doi:10.1177/0081246317742246

Martini, T., Verbey-Verutis, R., Grose, J., Clarke, B., \& Elder, A. (2019). Canadian undergraduates' reports of co-curricular involvement across the degree. Teaching and Learning Inquiry, 7(1), 103-119. doi:10.20343/teachlearninqu.7.1.7

McAuliffe, G., Jurgens, J. C., Pickering, W., Calliotte, J., Macera, A., \& Zerwas, S. (2006). Targeting low career confidence using the career planning confidence scale. Journal of Employment Counseling, 43(3), 117-129. doi:10.1002/j.2161-1920.2006.tb00011.x

McLoyd, V. C., Kaplan, R., Purtell, K. M., \& Huston, A. C. (2011). Assessing the effects of a work-based antipoverty program for parents on youth's future orientation and employment experiences. Child Development, 82(1), 113-132. doi:10.1111/j.14678624.2010.01544.x

McQuown Linnemeyer, R., \& Brown, C. (2010). Career maturity and foreclosure in student athletes, fine arts students, and general college students. Journal of Career Development, 37(3), 616-634. doi:10.1177/0894845309357049

Merino-Tejedor, E., Hontangas, P. M., \& Boada-Grau, J. (2016). Career adaptability and its relation to self-regulation, career construction, and academic engagement among Spanish university students. Journal of Vocational Behavior, 93, 92-102. doi:10.1016/ j.jvb.2016.01.005.

Merino-Tejedor, E., Hontangas, P. M., \& Petrides, K. V. (2018). Career adaptability mediates the effect of trait emotional intelligence on academic engagement. Revista de Psicodidactica. doi:10.1016/j.psicod.2017.10.001

Miles, J., \& Naidoo, A. V. (2017). The impact of a career intervention programme on South African Grade 11 learners' career decision-making self-efficacy. South African Journal of Psychology, 47(2), 209-221. doi:10.1177/0081246316654804

Millar, R., \& Shevlin, M. (2007). The development and factor structure of a career locus of control scale for use with school pupils. Journal of Career Development, 33(3), 224249. doi:10.1177/0894845306296643

Monteiro, S., Ferreira, J. A., \& Almeida, L. S. (2018). Self-perceived competency and selfperceived employability in higher education: the mediating role of career adaptability. Journal of Further and Higher Education. doi:10.1080/0309877X.2018.1542669

Murphy, D. A., Marelich, W. D., Herbeck, D. M., \& Cook, M. (2016). Career readiness and externalizing behaviors of children affected by maternal HIV/AIDS: 15-year outcomes of the PACT study. Vulnerable Children and Youth Studies, 11(3), 223-237. doi:10.1080/17450128.2016.1217113

Nagle, K., Newman, L. A., Shaver, D. M., \& Marschark, M. (2016). College and career readiness: Course taking of deaf and hard of hearing secondary school students. American Annals of the Deaf, 160(5), 467-482. doi:10.1353/aad.2016.0000

Negru-Subtirica, O., \& Pop, E. I. (2016). Longitudinal links between career adaptability and academic achievement in adolescence. Journal of Vocational Behavior, 93, 163-170. doi:10.1016/j.jvb.2016.02.006.

Negru-Subtirica, O., Pop, E. I., \& Crocetti, E. (2015). Developmental trajectories and reciprocal associations between career adaptability and vocational identity: A threewave longitudinal study with adolescents. Journal of Vocational Behavior, 88, 131142. doi:10.1016/j.jvb.2015.03.004

Neureiter, M., \& Traut-Mattausch, E. (2017). Two sides of the career resources coin: Career adaptability resources and the impostor phenomenon. Journal of Vocational Behavior, 98, 56-69. doi:10.1016/j.jvb.2016.10.002

Nilforooshan, P., \& Salimi, S. (2016). Career adaptability as a mediator between personality and career engagement. Journal of Vocational Behavior, 94, 1-10.

doi:10.1016/j.jvb.2016.02.010 
Nota, L., Ginevra, M. C., \& Soresi, S. (2012). The career and work adaptability questionnaire (CWAQ): A first contribution to its validation. Journal of Adolescence, 35, 15571569. doi:10.1016/j.adolescence.2012.06. 004

Oliveira, Í. M., Taveira, M. D. C., Cadime, I., \& Porfeli, E. J. (2016). Psychometric properties of a career exploratory outcome expectations measure. Journal of Career Assessment, 24(2), 380-396. doi:10.1177/1069072715580577

Oliveira, Í. M., Taveira, M., \& Porfeli, E. J. (2017). Career preparedness and school achievement of portuguese children: Longitudinal trend articulations. Frontiers in Psychology, 8, 618. doi:10.3389/fpsyg.2017.00618

Oliveira, Í. M., Taveira, M. C., Porfeli, E. J., \& Grace, R. C. (2018). Confirmatory study of the Multidimensional Scales of Perceived Self-Efficacy with children. Universitas Psychologica, 17(4). doi:10.11144/Javeriana.upsy17-4.csms

Öncel, L. (2014). Career Adapt-Abilities Scale: Convergent validity of subscale scores. Journal of Vocational Behavior, 85, 13-17. doi:10.1016/j.jvb.2014.03.006

Osipow, S. H., Carney, C. G., \& Barak, A. (1976). A scale of educational-vocational undecidedness: A typological approach. Journal of Vocational Behavior, 9(2), 233243. doi:10.1016/0001-8791(76)90081-6

Öztemel, K., \& Y1ldı-Akyol, E. (2019). The predictive role of happiness, social support, and future time orientation in career adaptability. Journal of Career Development. doi:10.1177/0894845319840437

Pan, J., Guan, Y., Wu, J., Han, L., Zhu, F., Fu, X., \& Yu, J. (2018). The interplay of proactive personality and internship quality in Chinese university graduates' job search success: The role of career adaptability. Journal of Vocational Behavior, 109, 14-26. doi:10.1016/j.jvb.2018.09.003

Park, C. J., Rottinghaus, P. J., Wang, Z., Zhang, T., Falk, N. A., \& Ko, S. J. (2018). Measurement invariance of the Career Futures Inventory-Revised across general and client samples. Journal of Career Assessment. doi:10.1177/1069072718816514

Park, I.-J. (2015a). The role of affect spin in the relationships between proactive personality, career indecision, and career maturity. Frontiers in Psychology, 6, 1754. doi:10.3389/fpsyg.2015.01754

Park, M.-s., \& Han, S.-h. (2016). A structural analysis on the decision-making level, career decision-making self-efficacy, career decision immersive, career preparation behavior, and self-determination of college students who participated in the training courses from lifelong educators. International Information Institute (Tokyo), 19(4), 1145. doi:10.14738/aivp.53.3406

Park, S. (2015b). Effects of discipline-based career course on nursing students' career search self-efficacy, career preparation behavior, and perceptions of career carriers. Asian Nursing Research, 9(3), 259-264. doi:10.1016/j.anr.2015.06.003

Patton, W., \& Creed, P. (2007). The relationship between career variables and occupational aspirations and expectations for Australian high school adolescents. Journal of Career Development, 34(2), 127-148. doi:10.1177/0894845307307471

Patton, W., \& Creed, P. A. (2002). The relationship between career maturity and work commitment in a sample of Australian high school students. Journal of Career Development, 29(2), 69-85. doi:10.1023/A:1019981502852

Patton, W., Creed, P. A., \& Watson, M. (2003). Perceived work related and non-work related barriers in the career development of Australian and South African adolescents. Australian Journal of Psychology, 55(2), 74-82. doi:10.1080/00049530412331312924

Perera, H. N., \& McIlveen, P. (2017). Profiles of career adaptivity and their relations with adaptability, adapting, and adaptation. Journal of Vocational Behavior, 98, 70-84. doi:10.1016/j.jvb.2016.10.001 
Peng, H., \& Johanson, R. E. (2006). Career maturity and state anxiety of Taiwanese college student athletes given cognitive career-oriented group counseling. Psychological Reports, 99(3), 805-812. doi:10.2466/PR0.99.3.805-812

Perry, J. C., Liu, X., \& Pabian, Y. (2010). School engagement as a mediator of academic performance among urban youth: The role of career preparation, parental career support, and teacher support. The Counseling Psychologist, 38(2), 269-295. doi:10.1177/0011000009349272

Perry, J. C., Wallace, E. W., \& McCormick, M. P. (2018). Making my future work: Evaluation of a new college and career readiness curriculum. Youth \& Society, 50(6), 841-866. doi:10.1177/0044118x16658221

Pinquart, M., \& Pfeiffer, J. P. (2015). Solving developmental tasks in adolescents with a chronic physical illness or physical/sensory disability: A meta-analysis. International Journal of Disability, Development and Education, 62(3), 249-264. doi:10.1080/1034912X.2015.1020922

Porfeli, E. J., \& Savickas, M. L. (2012). Career Adapt-Abilities Scale-USA Form: Psychometric properties and relation to vocational identity. Journal of Vocational Behavior, 80, 748-753. doi:10.1016/j. jvb.2012.01.009

Pouyaud, J., Vignoli, E., Dosnon, O., \& Lallemand, N. (2012). Career Adapt-Abilities ScaleFrance Form: Psychometric properties and relationships to anxiety and motivation. Journal of Vocational Behavior, 80, 692-697. doi:10.1016/j.jvb.2012.01.021

Poynton, T. A., Lapan, R. T., \& Marcotte, A. M. (2015). Financial planning strategies of high school seniors: Removing barriers to career success. The Career Development Quarterly, 63(1), 57-73. doi:10.1002/j.2161-0045.2015.00095.x

Praskova, A., Creed, P. A., \& Hood, M. (2013). Facilitating engagement in new career goals: the moderating effects of personal resources and career actions. International Journal for Educational and Vocational Guidance, 13, 115-134. doi:10.1007/s10775-0139242-2

Praskova, A., Hood, M., \& Creed, P. A. (2014). Testing a calling model of psychological career success in Australian young adults: A longitudinal study. Journal of Vocational Behavior, 85, 125-135. doi:10.1016/j. jvb.2014.04.004

Presbitero, A., \& Quita, C. (2017). Expatriate career intentions: Links to career adaptability and cultural intelligence. Journal of Vocational Behavior, 98, 118-126. doi:10.1016/j.jvb.2016.11.001

Prescod, D. J., \& Zeligman, M. (2018). Career adaptability of trauma survivors: The moderating role of posttraumatic growth. The Career Development Quarterly, 66(2), 107-120. doi:10.1002/cdq. 12126

Punch, R., Creed, P. A., \& Hyde, M. (2005). Predicting career development in hard-ofhearing adolescents in Australia. Journal of Deaf Studies and Deaf Education, 10(2), 146-160. doi:10.1093/deafed/eni015

Ramos, K., \& Lopez, F. G. (2018). Attachment security and career adaptability as predictors of subjective well-being among career transitioners. Journal of Vocational Behavior, 104, 72-85. doi:10.1016/j.jvb.2017.10.004

Rigotti, T., Schyns, B., \& Mohr, G. (2008). A short version of the occupational self-efficacy scale: Structural and construct validity across five countries. Journal of Career Assessment, 16(2), 238-255. doi:10.1177/1069072707305763

Rocha, M. (2012). Transferable skills representations in a Portuguese college sample: Gender, age, adaptability and vocational development. European Journal of Psychology of Education, 27, 77-90. doi:10.1007/ s10212-011-0067-4

Rocha, M. (2015). Predictors of the acquisition and portability of transferable skills: A longitudinal Portuguese case study on education. Higher Education, 69, 607-624. doi:10.1007/s10734-014-9793-2 
Rogers, M. E., Creed, P. A., \& Glendon, I. A. (2008). The role of personality in adolescent career planning and exploration: A social cognitive perspective. Journal of Vocational Behavior, 73(1), 132-142. doi:10.1016/j.jvb.2008.02.002

Rojewski, J. W., Lee, I. H., \& Hill, R. B. (2014). Participation patterns of Korean adolescents in school-based career exploration activities. Asia Pacific Education Review, 15(3), 473-482. doi:10.1007/s12564-014-9331-z

Rottinghaus, P. J., Buelow, K. L., \& Matyja, A. (2012). The career futures inventory-revised: Measuring dimensions of career adaptability. Journal of Career Assessment, 20, 123 139. doi:10.1177/ 1069072711420849

Rottinghaus, P. J., Day, S. X., \& Borgen, F. H. (2005). The career futures inventory: A measure of careerrelated adaptability and optimism. Journal of Career Assessment, 13, 3-24. doi:10.1177/ 1069072704270271

Rottinghaus, P. J., Eshelman, A., Gore, J. S., Keller, K. J., Schneider, M., \& Harris, K. L. (2017). Measuring change in career counseling: Validation of the Career Futures Inventory-Revised. International Journal for Educational and Vocational Guidance, 17(1), 61-75. doi:10.1007/s10775-016-9329-7

Rusu, A., Mairean, C., Hojbota, A., Gheramis, L. R., \& Gavriloaiei. (2015). Relationships of career adaptabilities with explicit and implicit self-concepts. Journal of Vocational Behavior, 89, 92-101. doi:10.1016/j. jvb.2015.05.003

Ryba, T. V., Zhang, C. Q., Huang, Z. J., \& Aunola, K. (2017). Career Adapt-Abilities Scale Dual Career Form (CAAS-DC): psychometric properties and initial validation in highschool student-athletes. Health Psychology and Behavioral Medicine, 5(1), 85-100. doi:10.1080/21642850.2016.1273113

Sadeghi, A., Baghban, I., Bahrami, F., Ahmadi, A., \& Creed, P. (2011). Validation of the short form of the career development inventory with an Iranian high school sample. International Journal for Educational and Vocational Guidance, 11(1), 29-38. doi:10.1007/s10775-011-9189-0

Salami, S. O. (2008). Gender, identity status and career maturity of adolescents in south west Nigeria. Journal of Social Science, 16(1), 35-49.

Santilli, S., Nota, L., Ginevra, M. C., \& Soresi, S. (2014). Career adaptability, hope and life satisfaction in workers with intellectual disability. Journal of Vocational Behavior, 85, 67-74. doi:10.1016/j.jvb.2014.02.011

Santini, S., Nota, L., \& Hartung, P. J. (2019). Efficacy of a group career construction intervention with early adolescent youth. Journal of Vocational Behavior, 111, 49-58. doi:10.1016/j.jvb.2018.06.007

Santos, P. J. (2007). Dificuldades de escolhas vocacional [career decison-making difficulties]. Coimbra, Portugal: Almedina.

Savickas, M. L. (1984). Career maturity: The construct and its measurement. The Career Development Quarterly, 32(4), 222-231. doi:10.1002/j.2164-585X.1984.tb01585.x

Savickas, M. L., Briddick, W. C., \& Watkins, C. E. (2002). The relation of career maturity to personality type and social adjustment. Journal of Career Assessment, 10(1), 24-49. doi:10.1177/1069072702010001002

Savickas, M. L., \& Porfeli, E. J. (2011). Revision of the career maturity inventory: The adaptability form. Journal of Career Assessment, 19, 355-374. doi:10.1177/1069072711409342

Savickas, M. L., \& Porfeli, E. J. (2012). Career Adapt-Abilities Scale: Construction, reliability, and measurement equivalence across 13 countries. Journal of Vocational Behavior, 80, 661-673. doi:10.1016/j.jvb. 2012.01.011

Schmidt, C. K., \& Nilsson, J. E. (2006). The effects of simultaneous developmental processes: Factors relating to the career development of lesbian, gay, and bisexual 
youth. The Career Development Quarterly, 55(1), 22-37. doi:10.1002/j.21610045.2006.tb00002.x

Schultheiss, D. E., \& Stead, G. B. (2004). Childhood career development scale: Scale construction and psychometric properties. Journal of Career Assessment, 12(2), 113 134. doi:10.1177/1069072703257751

Seok, C. B., Abd Hamid, H. S., \& Ismail, R. (2019). Psychometric properties of the Intrapreneurial Self-Capital Scale in Malaysian university students. Sustainability, 11(3), 9. doi:10.3390/su11030881

Shevlin, M., \& Millar, R. (2006). Career education: An application of latent growth curve modelling to career information-seeking behaviour of school pupils. British Journal of Educational Psychology, 76(1), 141-153. doi:10.1348/000709904x22386

Shin, J. Y., Kim, T. S., \& Ahn, J. (2018). Calling, career preparation behaviors, and meaning in life among south korean college students. Journal of College Student Development, 59(6), 734-748.

Shin, Y. J., \& Lee, J. Y. (2019). Self-focused attention and career anxiety: The mediating role of career adaptability. Career Development Quarterly, 67(2), 110-125. doi:10.1002/cdq. 12175

Shin, Y. J., \& Lee, J. Y. (2017). Attachment, career-choice pessimism, and intrinsic motivation as predictors of college students' career adaptability. Journal of Career Development, 44(4), 311-326. doi:10.1177/0894845316653472

Shulman, S., Vasalampi, K., Barr, Z., Livne, Y., Nurmi, J. E., \& Pratt, M. W. (2014).

Typologies and precursors of career adaptability patterns among emerging adults: A seven-year longitudinal study. Journal of Adolescence, 37, 1505-1515. doi:10.1016/j.adolescence.2014.06.003

Silva, A. D., Coelho, P., \& Taveira, M. C. (2017). Effectiveness of a career intervention for empowerment of institutionalized youth. Vulnerable Children and Youth Studies, 12(2), 171-181. doi:10.1080/17450128.2017.1282070

Skorikov, V. (2007). Continuity in adolescent career preparation and its effects on adjustment. Journal of Vocational Behavior, 70(1), 8-24. doi:10.1016/j.jvb.2006.04.007

Smedley, M., Levinson, E. M., Barker, W. F., \& DeAngelis, D. L. (2003). Differences in career maturity among adjudicated and nonadjudicated male students with and without disabilities. Journal of Employment Counseling, 40(3), 108. doi:10.1002/j.21611920.2003.tb00861.x

Son, S. (2018). The more reflective, the more career-adaptable: A two-wave mediation and moderation analysis. Journal of Vocational Behavior, 109, 44-53. doi:10.1016/j.jvb.2018.09.004

Soresi, S., Nota, L., \& Ferrari, L. (2012). Career Adapt-Abilities Scale-Italian Form: Psychometric properties and relationships to breadth of interests, quality of life, and perceived barriers. Journal of Vocational Behavior, 80, 705-711. doi:10.1016/j.jvb.2012.01.020

Stoeber, J., Mutinelli, S., \& Corr, P. J. (2016). Perfectionism in students and positive career planning attitudes. Personality and Individual Differences, 97, 256-259. doi:10.1016/j.paid.2016.03.065

Stoltz, K. B., Wolff, L. A., Monroe, A. E., Farris, H. R., \& Mzahreh, L. G. (2013). Adlerian lifestyle, stress coping, and career adaptability: Relationships and dimensions. Career Development Quarterly, 61, 194-209. doi:10.1002/j.2161-0045.2013.00049.x

Strauser, D., Klosky, J. L., Brinkman, T. M., Wong, A. W., Chan, F., Lanctot, J., . . Ness, K. K. (2015). Career readiness in adult survivors of childhood cancer: a report from the St. Jude Lifetime Cohort Study. Journal of Cancer Survivorship, 9(1), 20-29. doi:10.1007/s11764-014-0380-4 
Strauser, D., Wagner, S., Wong, A. W., \& O'Sullivan, D. (2013). Career readiness, developmental work personality and age of onset in young adult central nervous system survivors. Disability and Rehabilitation, 35(7), 543-550. doi:10.3109/09638288.2012.703754

Stringer, K., Kerpelman, J., \& Skorikov, V. (2011). Career preparation: A longitudinal, process-oriented examination. Journal of Vocational Behavior, 79(1), 158-169. doi:10.1016/j.jvb.2010.12.012

Stringer, K., Kerpelman, J., \& Skorikov, V. (2012). A longitudinal examination of career preparation and adjustment during the transition from high school. Developmental Psychology, 48(5), 1343-1354. doi:10.1037/a0027296

Storme, M., Celik, P., \& Myszkowski, N. (2019). Career decision ambiguity tolerance and career decision-making difficulties in a French sample: The mediating role of career decision self-efficacy. Journal of Career Assessment, 27(2), 273-288. doi:10.1177/1069072717748958

Super, D. E. (1957). The psychology of careers: An introduction to vocational development. New York, NY: Harper \& Brothers.

Super, D. E., \& Hall, D. T. (1978). Career development: Exploration and planning. Annual Review of Psychology, 29(1), 333-372. doi:10.1146/annurev.ps.29.020178.002001

Sverko, I., \& Babarovic, T. (2019). Applying career construction model of adaptation to career transition in adolescence: A two-study paper. Journal of Vocational Behavior, 111, 59-73. doi:10.1016/j.jvb.2018.10.011

Sverko, I., \& Babarovic, T. (2016). Integrating personality and career adaptability into vocational interest space. Journal of Vocational Behavior, 94, 89-103. doi:10.1016/j.jvb.2016.02.017

Taber, B. J., \& Blankemeyer, M. (2015). Future work self and career adaptability in the prediction of proactive career behaviors. Journal of Vocational Behavior, 86, 20-27. doi:10.1016/j.jvb.2014.10.005

Tak, J., \& Lee, K.-H. (2003). Development of the Korean career indecision inventory. Journal of Career Assessment, 11(3), 328-345. doi:10.1177/1069072703254503

Talib, J. A., Salleh, A., Amat, S., Ghavifekr, S., \& Ariff, A. M. (2015). Effect of career education module on career development of community college students. International Journal for Educational and Vocational Guidance, 15(1), 37-55. doi:10.1007/s10775014-9279-x

Talib, M. A., \& Aun, T. K. (2009). Predictors of career indecision among malaysian undergraduate students. European Journal of Social Sciences, 8(2), 215-224.

Teng, L. Y., Morgan, G. A., \& Anderson, S. K. (2001). Career development among ethnic and age groups of community college students. Journal of Career Development, 28(2), 115-127. doi:10.1023/A:1012590726856

Teychenne, M., Parker, K., Teychenne, D., Sahlqvist, S., Macfarlane, S., \& Costigan, S. (2019). A pre-post evaluation of an online career planning module on university students' career adaptability. Journal of Teaching and Learning for Graduate Employability, 10(1), 42-55. doi:10.21153/jtlge2019vol10nolart781

Tian, Y., \& Fan, X. (2014). Adversity quotients, environmental variables and career adaptability in student nurses. Journal of Vocational Behavior, 85, 251-257. doi:10.1016/j.jvb.2014.07.006

Tien, H. L. S., Lin, S. H., Hsieh, P. J., \& Jin, S. R. (2014). The Career Adapt-Abilities Scale in Macau: Psychometric characteristics and construct validity. Journal of Vocational Behavior, 84, 259-265. doi:10. 1016/j.jvb.2014.01.005

Tsai, C.-T. S., Hsu, H., \& Yang, C.-C. (2017). Career decision self-efficacy plays a crucial role in hospitality undergraduates' internship efficacy and career preparation. Journal 
of Hospitality, Leisure, Sport \& Tourism Education, 21(A), 61-68. doi:10.1016/j.jhlste.2017.08.002

Tolentino, L. R., Garcia, P. R. J. M., Lu, V. N., Restubog, S. L. D., Bordia, P., \& Plewa, C. (2014). Career adaptation: The relation of adaptability to goal orientation, proactive personality, and career optimism. Journal of Vocational Behavior, 84, 39-48. doi:10.1016/j.jvb.2013.11.004

Tolentino, L. R., Garcia, P. R. J. M., Restubog, S. L. D., Bordia, P., \& Tang, R. L. (2013). Validation of the Career Adapt-Abilities Scale and an examination of a model of career adaptation in the Philippine context. Journal of Vocational Behavior, 83, 410 418. doi:10.1016/j.jvb.2013.06.013

Tolentino, L. R., Sedoglavich, V., Lu, V. N., Garcia, P. R. J. M., \& Restubog, S. L. D. (2014). The role of career adaptability in predicting entrepreneurial intentions: A moderated mediation model. Journal of Vocational Behavior, 85, 403-412. doi:10.1016/j.jvb.2014.09.002

Tolentino, L. R., Sibunruang, H., \& Garcia, P. R. J. M. (2018). The role of self-monitoring and academic effort in students' career adaptability and job search self-efficacy. Journal of Career Assessment. doi:10.1177/1069072718816715

Trice, A. D., Haire, J. R., \& Elliott, K. A. (1989). A career locus of control scale for undergraduate students. Perceptual and Motor Skills, 69(2), 555-561. doi:10.2466/pms.1989.69.2.555

Udayar, S., Fiori, M., Thalmayer, A. G., \& Rossier, J. (2018). Investigating the link between trait emotional intelligence, career indecision, and self-perceived employability: The role of career adaptability. Personality and Individual Differences, 135, 7-12. doi:10.1016/j.paid.2018.06.046

Urbanaviciute, I., Kairys, A., Pociute, B., \& Liniauskaite, A. (2014). Career adaptability in Lithuania: A test of psychometric properties and a theoretical model. Journal of Vocational Behavior, 85, 433-442. doi:10. 1016/j.jvb.2014.09.005

Urbanaviciute, I., Pociute, B., Kairys, A., \& Liniauskaite, A. (2016). Perceived career barriers and vocational outcomes among university undergraduates: Exploring mediation and moderation effects. Journal of Vocational Behavior, 92, 12-21. doi:10.1016/j.jvb.2015.11.001.

Umukoro, O., \& Okumare, D. (2017). Exogenous determinants of entrepreneurial intuition and the mediatory role of psychological capital among potential youth entrepreneurs. Journal of Global Entrepreneurship Research, 7(1), 1-13. doi:10.1186/s40497-0170078-y

Uy, M. A. (2014). Proactivity, adaptability and boundaryless career attitudes: The mediating role of entrepreneurial alertness. Journal of Vocational Behavior, 86, 115-123. doi:10.1016/j.jvb.2014.11.005

Van Raalte, J. L., Andrews, S. R., Cornelius, A. E., Brewer, B. W., \& Petitpas, A. J. (2017). Student-athlete career self-efficacy: Workshop development and evaluation. Journal of Clinical Sport Psychology, 11(1), 1-13. doi:10.1123/jcsp.2016-0015

Van Vianen, A. E. M., Klehe, U.-C., Koen, J., \& Dries, N. (2012). Career Adapt-Abilities Scale-Netherlands Form: Psychometric properties and relationships to ability, personality, and regulatory focus. Journal of Vocational Behavior, 80, 716-724. doi:10.1016/j.jvb.2012.01.002

Vilhjálmsdóttir, G., Kjartansdóttir, G. B., Smáradóttir, S. B., \& Einarsdóttir, S. (2012). Career Adapt-Abilities Scale-Icelandic Form: Psychometric properties and construct validity. Journal of Vocational Behavior, 80, 698-704. doi:10.1016/j.jvb.2012.01.013

Villarreal, S., Montoya, J. A., Duncan, P., \& Gergen, E. (2018). Leadership styles predict career readiness in early college high-school students. Psychology in the Schools, 55(5), 476-489. doi:10.1002/pits.22131 
Walker, T., Pearson, F., \& Murrell, P. (2010). Quality of effort and career preparation differences between African American and White community college students. Community College Journal of Research and Practice, 34(9), 738-754. doi:10.1080/10668920902917450

Wang, Z., \& Fu, Y. (2015). Social support, social comparison, and career adaptability: A moderated mediation model. Social Behavior and Personality: An International Journal, 43(4), 649-659. doi:10.2224/sbp.2015.43.4.649.

Wang, D., Hou, Z. J., Ni, J., Tian, L., Zhang, X., Chi, H. Y., \& Zhao, A. (2018). The effect of perfectionism on career adaptability and career decision-making difficulties. Journal of Career Development. doi:10.1177/0894845318803192

Werch, C. E., Bian, H., Moore, M. J., Ames, S. C., DiClemente, C. C., Thombs, D., \& Pokorny, S. B. (2008). Brief multiple behavior health interventions for older adolescents. American Journal of Health Promotion, 23(2), 92-96. doi:10.4278/ajhp.07040533

Wilkins-Yel, K. G., Roach, C. M. L., Tracey, T. J. G., \& Yel, N. (2018). The effects of career adaptability on intended academic persistence: The mediating role of academic satisfaction. Journal of Vocational Behavior, 108, 67-77. doi:10.1016/j.jvb.2018.06.006

Wilkins, K. G., Santilli, S., Ferrari, L., Nota, L., Tracey, T. J., \& Soresi, S. (2014). The relationship among positive emotional dispositions, career adaptability, and satisfaction in Italian high school students. Journal of Vocational Behavior, 85, 329 338. doi:10.1016/j.jvb.2014.08.004

Wong, S.-W., Chui, Y. H., Chan, Y. C., Ting, S. R., \& Lam, J. K. (2016). Enhancing students career readiness through peer counselling programme in Hong Kong. Australian Journal of Career Development, 25(1), 23-32. doi:10.1177/1038416215612821

Wood, M., Taylor, S., Carroll, A., \& Hansen, N. C. (2017). Surveying employment listings to inform curricula of environmental science degree programs. Journal of Environmental Studies and Sciences, 7(2), 346-354. doi:10.1007/s13412-016-0401-x

Wu, M., \& Chang, C.-C. (2009). Relationship of advisory mentoring to MBA career maturity: An anticipatory socialization perspective. Journal of Career Development, 35(3), 248264. doi: $10.1177 / 0894845308327272$

Xiao, J. J., Newman, B. M., \& Chu, B. S. (2018). career preparation of high school students: a multi-country study. Youth \& Society, 50(6), 818-840. doi: $10.1177 / 0044118 \times 16638690$

$\mathrm{Xu}, \mathrm{H}$. (2019). Career Indecision Profile-Short: Reliability and validity among employees and measurement invariance across students and employees. Journal of Career Assessment. doi:10.1177/1069072719831975

Xu, H., \& Tracey, T. J. G. (2015). Career Decision Ambiguity Tolerance Scale: Construction and initial validations. Journal of Vocational Behavior, 88, 1-9. doi:10.1016/j.jvb.2015.01.006.

Yates, J. A. R., Wong, A. W. K., Strauser, D. R., \& Sears, S. J. H. (2017). The impact of type $\mathrm{D}$ personality traits on the career readiness of college students with and without disabilities. Rehabilitation Counseling Bulletin, 60(2), 67-76. doi:10.1177/0034355215610082

Ye, L. (2015). Work values and career adaptability of Chinese university students. Social Behavior and Personality: An International Journal, 43(3), 411-421. doi:10.2224/sbp.2015.43.3.411

Yon, K. J., Choi, W., \& Goh, M. (2013). Career maturity growth curve and sex-role stereotypes of Korean adolescents. Journal of Career Development, 40(3), 203-222. doi: $10.1177 / 0894845312445515$ 
Yon, K. J., Joeng, J.-R., \& Goh, M. (2012). A longitudinal study of career maturity of Korean adolescents: The effects of personal and contextual factors. Asia Pacific Education Review, 13(4), 727-739. doi:10.1007/s12564-012-9232-y

Yousefi, Z., Abedi, M., Baghban, I., Eatemadi, O., \& Abedi, A. (2011). Personal and situational variables, and career concerns: Predicting career adaptability in young adults. The Spanish Journal of Psychology, 14, 263-271. doi:10.5209/rev_SJOP.2011.v14.n1.23

Zhang, Z.-Y., Rong, Y., \& Guan, Y.-J. (2006). The reliability and validity of a Chinese version of the college students' career maturity inventory. Journal of Southwest China Normal University (Humanities and Social Sciences Edition), 5, 002.

Zhang, J., Chen, G., \& Yuen, M. (2018). Validation of the Vocational Identity Status Assessment (VISA) using Chinese technical college students. Journal of Career Assessment. doi:10.1177/1069072718808798

Zhou, W., Guan, Y., Xin, L., Mak, M. C. K., \& Deng, Y. (2016). Career success criteria and locus of control as indicators of adaptive readiness in the career adaptation model. Journal of Vocational Behavior, 94, 124-130. doi:10.1016/j.jvb.2016.02.015.

Zhou, M., \& Lin, W. P. (2016). Adaptability and Life Satisfaction: The moderating role of social support. Frontiers in Psychology, 7. doi:10.3389/fpsyg.2016.01134

Zhuang, M., She, Z., Cai, Z., Huang, Z., Xiang, Q., Wang, P., \& Zhu, F. (2018). Examining a sequential mediation model of Chinese university students' well-being: A career construction perspective. Frontiers in Psychology, 9(APR).

doi:10.3389/fpsyg.2018.00593 


\section{Appendix B}

\section{Table B1}

Classification of Measures and Dimensions Used in the Career Preparedness Literature into Attitudes, Knowledge and Competencies, and

\section{Behaviors}

\section{Assessed constructs}

Career preparedness attitudes

Career maturity attitudes (total score) ${ }^{\mathrm{a}}$

Career planning ${ }^{\mathrm{b}}$

Career exploration $^{\mathrm{c}}$

Career (un)certainty

Corresponding Measures

CMI (Crites, 1978); CMI-R (Crites \& Savickas, 1996); CDI-A (Lokan, 1984); CDI (Thompson et al., 1981); Chinese career maturity inventory (Zhang, Rong, \& Guan, 2006); medical career development inventory (Savickas, 1984); career maturity attitude scale (Han \&Lee, 1997); Korean career maturity inventory (Jang, Lim, \& Song, 1992) ; NYPI study (Kim \& Oh, 2013).

CDI; CDI-A; career planning scale (Skorikov, 2007); career planning scale (Abele \& Wiese, 2008); KELS (Kim, Ryu, \& Kim, 2006); childhood career development scale (Schultheiss \& Stead, 2004); career planning ability questionnaire (Abd-Hanid, 2007); Taiwanese career attitude maturity inventory (Huang, 2001); career readiness scale (Chui, 2012); Positive attitude toward career planning scale (Koivisto et al., 2011).

Career exploration (Kracke, 2001); CDI; CDI-A; Taiwanese career attitude maturity inventory.

Career decision scale (Osipow, 1987); vocational certainty scale (Santos, 2007); daidalos inventory (Dybwad, 2008).

\section{Example papers}

Busacca \& Taber (2002); Creed \& Patton (2003); Creed et al., (2007); Punch et al., (2005); Kornspan \& Etzel (2001).

Creed et al., (2002); Hirschi et al., (2011); Hughes (2011); Jaensch et al., (2016); Janeiro (2010); Koivisto et al., (2011); Patton \& Creed (2002); Perry et al., (2010); Stringer et al., (2012); Wong et al., (2016).

Hughes (2011); Rogers et al., (2008); Savickas et al., (2002); Wu \& Chang (2009).

Creed et al., (2002); Punch et al., (2005). 
Career decidedness / indecision

Confidence

Exploratory outcome expectations

Decision making self-efficacy

Career locus of control

Dysfunctional beliefs
Chinese career maturity inventory; KELS; my vocational situation (Holland, Daiger, \& Power, 1980); EE index (Hirschi \& Läge, 2007); CMI; commitment to career choice scale (Blustein, Ellis, \& Devenis, 1989); career decision scale; career decision making difficulties questionnaire (Gati, Krausz, \& Osipow, 1996); career decision making difficulties questionnaire - revised (Gati \& Osipow, 2000); CFI (Chartrand et al., 1990); career maturity attitude scale.

Occupational self-efficacy scale (Rigotti, Schyns \& Mohr, 2008); career planning confidence scale (McAuliffe et al., 2006); career self-efficacy (Caza, Brower, \& Wayne, 2015); career confidence (Skorikov, 2007).

Career exploratory outcome expectations scale (Oliveira et al., 2016).

Career decision making self-efficacy scale - short form (Betz, Klein \& Taylor, 1996); career choice self-efficacy scale (Koivisto et al., 2011); career readiness scale.

Career locus of control scale (Millar \& Shevlin, 2007); career development locus of control scale (Trice, Haire, \& Elliot, 1989).

Career decision making difficulties questionnaire; career decision making difficulties questionnaire revised.
Akos et al., (2004); Creed \& Patton (2003); Dipeoulu et al., (2012); Hirschi et al., (2011); Jaensch et al., (2016); Kleiman et al., (2004); Patton \& Creed (2007);

Strauser et al., (2015); Skorikov (2007).

Hirschi \& Hermann (2013); Jaensch et al., (2016).

Oliveira et al., (2017).

Koivisto et al., (2011); Punch et al., (2005); Wong et al., (2016).

Kornspan \& Etzel (2001).

Fan et al., (2014); Kleiman et al (2004). 
Adaptability resources

Other attitudes: e.g., career search self-efficacy; optimism; readiness to make a career decision; readiness to engage in vocational development behaviors; career preparation satisfaction; compromise, independence, involvement, orientation.
Career adapt-abilities scale (Savickas \& Porfeli, 2012);

Career futures inventory (Rottinghaus et al., 2005); CMI

Form C (Savickas \& Porfeli, 2011)

CMI; Chinese career maturity inventory; Taiwanese career attitude maturity inventory; medical career development inventory; occupational self-efficacy scale; multidimensional scale of perceived self-efficacy (Bandura, 1990); planned happenstance career inventory (Kim et al., 2014); custom items; career preparation satisfaction scale (Kim et al., 2016).
Guan et al (2015); Corr \& Mutinelli (2017); Chi, Leuty, Bullock-Yowell, \& Dahlen (2018)

Hardré \& Hackett (2015); Hardin \& Leong (2004); Hirschi et al., (2015); Kim et al., (2016); Koivisto et al., (2011); Oliveira et al., (2017); Park (2015b); Wu \& Chang (2009).

Career preparedness knowledge and competencies

\section{Career development knowledge (total CDI; CDI-A.}

score)

Career maturity competence (total score)

Knowledge of decision making

Knowledge of preferred occupation

Knowledge of world of work

Lack of information pertaining to self, occupations, stages of decision making, ways of obtaining additional information
CMI-R.

CDI; CDI-A; career planning scale (Liptak, 2008).

CDI; career planning scale (Liptak, 2008).

CDI; CDI-A; career planning scale (Liptak, 2008).

Career decision making difficulties questionnaire-revised; career decision making difficulties questionnaire.
Creed \& Patton (2003); Creed et al., (2007).

Creed et al., (2007); Dipeolu et al., (2012).

Creed et al., (2002); Jawarneh (2016); Savickas et al., (2002).

Jawarneh (2016); Smedley et al., (2003).

Creed et al (2002); Jawarneh (2016); Savickas et al., (2002).

Gaffner \& Hazler (2002); Kleiman et al., (2004). 
Lack of decision-making competence

Other: e.g., career research skills; generating occupational options; skills to access resources to support aspirations; integrating self and career information; acquisition of knowledge and skills pertaining to career development; preparedness for obstacles; career preparedness skills

Career preparedness behaviors

Self-exploration ${ }^{\mathrm{d}}$

Environment exploration ${ }^{\mathrm{d}}$

Career exploration (self and environment exploration combined $)^{\mathrm{d}}$

Career planning ${ }^{\mathrm{e}}$

Career preparation actions and behaviors, and adapting responses (e.g., attending career lectures, participating in counselling, asking others about their jobs, looking for information about careers, sought career advice, sought career support)

Implementation of career information
CTI (Peterson et al., 2002).

Custom items; career planning confidence scale; career behaviors \& knowledge scale (Casey Family Foundation, 2013).
Belser et al., (2017); Yates et al., (2017).

Clair et al., (2017); Koivisto et al., (2011); Walker et al., (2010).
Career exploration scale (Hirschi, 2009); Career exploration survey (Stumpf et al., 1983)

Career exploration scale (Hirschi, 2009); Career exploration survey (Stumpf et al., 1983)

KELS; childhood career exploration inventory (Oliveira et al., 2016); career exploratory behavior (Athanasou, 1986); career readiness scale.

Career planning scale (Liptak, 2008).

Custom items; career preparation behavior scale (Kim, 2003); career preparation behaviors (Blau, 1993); college and career readiness counselling support scale (Lombardi et al., 2013.

Medical career development inventory; career planning
Hirschi et al., (2011); Hirschi et al., (2015); Li et al. (2015)

Hirschi et al., (2011); Hirschi et al., (2015); Li et al., (2015).

Oliveira et al (2017); Shevlin \& Millar (2006); Wong et al., (2016).

Jawarneh (2016)

Clair et al., (2017); Kim et al., (2016); McLoyd et al., (2011); Tsai et al., (2017); Werch et al., (2007).

Jawarneh (2016) 
(e.g., starting an educational program) scale.

Note. $\mathrm{CMI}=$ Career maturity inventory; CMI-R $=$ Career maturity inventory revised; CDI = Career development inventory; CDI-A $=$ Career development inventory Australia; NYPI = National youth policy institute (Korea); KELS = Korean educational longitudinal survey; $\mathrm{CFI}=\mathrm{Career}$ factors inventory; CTI = Career thoughts inventory. All references included in this table appear in Appendix A. For the measures, a reference is only included the first time a measure appears. References are included again only when two scales have the same name.

${ }^{a}$ We group these attitudes together because either subscales were combined into a total score meaning it was not possible to distinguish individual attitudes from each other (e.g., CMI, CMI-R) or the items contained a mix of different attitudes. ${ }^{b}$ When authors used these measures of career planning, they conceptualized and/or measured career planning as an attitude. ${ }^{c}$ When authors used these measures of career exploration, they conceptualized and/or measured career exploration as an attitude. ${ }^{\mathrm{d}}$ When authors used these measures of exploration (self-, environment-, or a combination of the two), they conceptualized and/or measured exploration as a behavior. ${ }^{\mathrm{e}}$ When authors used this measure of planning they conceptualized and/or measured planning as a behavior. 